\title{
Books in the British Raj: The Contradictions of Liberal Imperialism
}

\section{Citation}

Darnton, Robert. 2001. Books in the British Raj: The contradictions of liberal imperialism. In Stephan Füssel, ed., Sonderdruck aus Gutenberg-Jahrbuch, 36-59. Mainz: Gutenberg-Ges. Previously published as "Literary Surveillance in the British Raj: The Contradictions of Liberal Imperialism" in Book History 4:133-176.

\section{Published Version}

http://dx.doi.org/10.1353/bh.2001.0007

\section{Permanent link}

http://nrs.harvard.edu/urn-3:HUL.InstRepos:2625468

\section{Terms of Use}

This article was downloaded from Harvard University's DASH repository, and is made available under the terms and conditions applicable to Other Posted Material, as set forth at http:// nrs.harvard.edu/urn-3:HUL.InstRepos:dash.current.terms-of-use\#LAA

\section{Share Your Story}

The Harvard community has made this article openly available.

Please share how this access benefits you. Submit a story.

\section{Accessibility}


Books in the British Raj: The Contradictions of Liberal Imperialism Robert Darnton

William Lawler made a most unlikely literary policeman. He was a librarian, a learned librarian, who looked out on the teeming city of Calcutta from the perspective of Roman antiquity and Victorian morality. Before him, spread out on a table, lay a huge sheet of paper divided into sixteen columns. Behind him, in endless rows of shelves, were books, a huge harvest of books from Bengal in the year 1879 . Lawler's job was to fill in the columns.

The first columns posed no problem. They organized the information required for the registration of new books; and their printed headings conformed to Act XXV of the Governor General of India in Council for 1867: language of text, author, subject, place of printing and publication, name of printer and publisher, date of publication, number of pages, format, edition, pressrun, printing by movable type or lithography, price, owner of copyright. All this information had been supplied by the publishers, along with three deposit copies of the books to be registered. By recording it, Lawler conferred a legal existence on the books, because any unregistered publication was deemed to be outside the law, and its publisher or printer could be punished with a two year jail sentence and a 5000 rupee fine. Once he had had his book registered and paid two rupees, the publisher acquired a copyright for all of British India. Lawler used the deposit copies to build the Bengal Library into a great repository of literature. And the government of Bengal used the filled-out forms to keep a record of all the books published in the province. It printed them in the form of a "catalogue", which it issued four times a year as a supplement to its official gazette. The Indian Civil Service (ICS) tried to keep track of books in the same way that it compiled information on grain harvests, irrigation ditches, railroads, and cattle. ${ }^{1}$

But books were different, because they could be explosive. The catalogues, despite their innocent-sounding name, were not available to the general public. They circulated secretly within the channels of the ICS--"A" matter deemed to be "confidential"--along with identical catalogues from the other provincial governments. Taken together, they provided the agents of the Raj with a running account of everything in the subcontinent that appeared in print--or at least everything that printers and publishers submitted for registration. The catalogue entries from 1868 to 1905 cover about 200,000 titles--more, by far, than the total output in France during the Age of Enlightenment. ${ }^{2}$ For Bengal alone, the catalogues from those years run to fifteen enormous volumes, each containing 500 pages or more, each page covered with small print. Their scale is staggering: more than a million words, printed with precision in sixteen standard columns. They show the ICS talking to itself about the "natives", a discourse on literature by the colonial authorities at the high tide of imperialism--or, to invoke Foucault's formula, knowledge and power.

Lawler satisfied the discursive requirements of his job when he filled in the blank space under the last of the rubrics, column sixteen: "Remarks." He summarized the narratives of novels, poems, and plays in a way that would make their moral clear for his own readers, the men who ruled over the "natives" in the ICS. Thus his remarks on the Bengali epic poem, Vana-Vihangini or The Female Bird of the Forest:

The present work of eight chapters commences with a touching appeal to Mother India, whose sad lot is deplored, and the oppression at the hands of the Yavans (or foreigners) pronounced unbearable. The first chapter contains an account of a Brahmin who supported himself and 
his wife Sundari in a forest by alms, till one day a Nabab [provincial governor] of Bengal, who came on a hunting excursion, chanced to alight there, saw his wife, and during his absence took her away. The second describes the return of the Brahmin husband after the usual day's begging. In the third he finds his wife gone, and is in deep distress thereat. In the fourth chapter, advice is given to the people of Bengal to be more united and act in concert, whereby they will gain strength and recover their lost possessions. The fifth depicts Sundari's distress in the Nabab's house, where she refused to eat and was prepared to kill herself, and how she was eventually released by the wife of the Nabab. In the sixth, the Brahmin husband and wife meet again in the forest and spend their time in much happiness, till in chapter seven they are arrested and taken by the orders of the Nabab. And in chapter eight the husband Sharat is executed, whereupon his wife Sundari dies broken-hearted. From pages 50-55 in chapter three, the poet digresses to portray in forcible language the subjection of the Aryan Bengali race to foreigners, who have placed their feet on the heads of Brahmins, but that the time must come, though it may be distant, when the Aryans will be freed from the yoke. ${ }^{3}$

However faithful he may have been to the original, Lawler retold the tale in a way that would give a district magistrate in the Punjab or a secretary in the India Office in London the sensation of knowing what the "natives" were up to when they published books.

They were up to no good. True, some books celebrated the beneficence of the Raj: law courts, railroads, electricity, cricket, and all the rest. Thus Daiva-lata or Creeper of Providence: "The writer...praises the English for their just administration and hopes that they will long continue to rule the country and that all India should be grateful for the benefits received from English rule." Samya or Equality even drew on Mill and Carlyle in order to attack the caste system: "...A few more works of this kind would make a revolution in the vast quantity of sluggish and silly Bengali literature of the present day." But such laudable works were the exception. The "natives" had an unfortunate tendency to seek amusement in their literature: Dekhilahansi-paya or Could Anyone But See the Sight He Would Laugh, a novella about the mishaps of a dim-witted younger brother, was "...one of the altogether silly tales which finds a ready audience amongst the natives, as it tends to excite laughter." As Lawler saw them, the Indians were children, who liked chapbook adventure stories and fairy tales, or printed versions of plays derived from the Ramayana, or worse: bawdy accounts of Krishna's dallying with the milkmaids, a perennial favorite adapted from the Mahabharata. Jagannather Rath-arohana-o-Kamini-ranjana or The Pleasure of Females took the Krishna theme far beyond the limits of decency, as Lawler understood them. He deplored it as a compendium of "...the most openly vulgar and obscene observations ever made, not even having the semblance of an excuse for the public good. It should be at once suppressed." Rahasya-pratibha or Mysteries revealed, a non-fiction account of crime in Calcutta, was equally offensive to Lawler's Victorian sensibility:

The production is devoid of any merit, the style is colloquial, and the sentiments are obscene.... The fact of its publication is a discredit on Bengali literature and the taste of the native reading public....It is 
devoutly to be wished that some means were available for putting a stop to the threatened publication of more trash like this in a second volume. ${ }^{4}$

The message is clear enough, but it raises problems; for the implicit readers of column sixteen were the masters of India: Why did they not ban the books that Lawler considered so reprehensible? And if they did not intend to repress any "native" literature, why did they follow its production in such exhaustive detail? What was the point of the gigantic secret catalogues? Evidently the connections between imperialism and literature were more complex than one might think. In order to make sense of them, it might be helpful to begin by considering the peculiar character of the book and of the Raj in nineteenth-century India.

The printed book in India was both very old and very new when the GovernorGeneral tried to bring it under his control by the Press and Registration of Books Act of 1867. Printing had existed on the subcontinent since 1556, when Joao de Bustamente set up a press in Goa. But it remained confined to tiny enclaves of missionaries scattered along the coasts, and the total number of publications, including pamphlets and news-sheets, came to less than 2000 titles by $1800 .^{5}$ According to a leading authority, the early history of printing in India can be divided into three periods: pre-incunabula, 1556-1800; incunabula, 1801-1867; and postincunabula, 1868-1900. ${ }^{6}$ That chronology may seem like nothing more than a bibliographer's joke, but it illustrates a fundamental point: the printed book did not penetrate deeply into Indian society until the second half of the nineteenth century, and even then it faced formidable obstacles: mass illiteracy and dozens of mutually incomprehensible languages.

The act of 1867 was but one of several attempts to restore order in a world still shaking from the after-shocks of the sepoy Mutiny and peasant uprisings of 18571858. The Mutiny--or Revolt or the First War of Independence, as some Indians prefer to call it--had exposed the fragility of the British hold on power. Areas larger than Britain itself had risen in revolt. Although the native soldiers remained loyal throughout most of the subcontinent, the sepoys of the Raj's heartland, the Gangetic territories from Delhi to Calcutta, had shown that they could not be trusted and, equally disturbing, that they had not been understood. Who would have thought that the introduction of a new rifle, the breechloading Enfield, would have provided the spark for the conflagration? In order to load it, the soldiers had to bite off the tips of the cartridges; and that, to them, was unthinkable, because the cartridges were sealed with the fat of pigs and the grease of cows, making them an abomination to Muslims and Hindus alike. The sepoys thought the sahibs were trying to defile them in order to make them lose caste and convert to Christianity. When their officers talked of military modernization, the soldiers smelled a missionary plot. And their suspicions were confirmed by the Enlistment Act of 1856, which threatened them with the prospect of being shipped across the Bay of Bengal to fight the white man's wars in Burma. By crossing "dark waters" into alien territory, high caste sepoys would become permanently polluted and especially vulnerable to conversion. Forty thousand of them came from the rich province of Oudh, which the British had annexed in the same year, despite the most sacred treaty obligations. But what did the British understand of sacredness? In a fit of "liberal" reforms, they had forbidden sati (the self-immolation of widows on the funeral pyres of their husbands) and permitted 
widow remarriage, another bitter pill forced down native throats in 1856, the year of abominations.

When the British inspected the devastation produced by the revolt, they began to measure the cultural distance that separated them from the "natives." Many of them withdrew into the world of the cutcherry and the club, reinforced in their racism by reports of black men ambushing women and children and throwing corpses down wells. Strange stories circulated about fakhirs and mullas who had supposedly prepared the Mutiny by passing around red-tinged chapattis (native bread) among the troops or, according to a later version, daubing cow dung on trees. Everything indicated that the "natives" and their conquerors lived in separate mental worlds. But to hold on to their conquests, the British needed to understand the Indians, not merely to defeat them.

By 1857 , the rough-and-ready phase of imperialism had come to an end. Clive's plundering, Wellesley's rapacity, Auckland's aggression, Napier's butchery, and Dalhousie's duplicitous diplomacy had brought most of the subcontinent under British control. After 1858, the British sought to increase their power by expanding their knowledge. They had already acquired considerable mastery of Indian languages--the classical languages, Sanskrit, Persian, and Arabic, and dozens of the vernacular tongues; and district officers had long prided themselves on "knowing the country." But two years of desultory study at Haileybury College followed by a few months in Calcutta did not make the agents of the East India Company into "Orientalists". The best of them learned to tap "native informants": holy men, barbers, foresters, bazaar merchants, prostitutes, midwives, astrologers, watchmen, pilgrims--descendants, all, of the harkaras and kasids, or intelligence-gatherers and runners, who had made the Mughal Empire into a vast information system. But most agents of the Company Raj had hardly begun to know their way around one district before they were transferred to another. The Mutiny caught them completely by surprise. Parliament abolished the Company in 1858, brought India under the direct rule of the Crown, and ruled through an administration that depended on modern modes of information gathering--that is, on an endless flow of words on paper. The ICS, recruited since 1853 by means of competitive examination, produced reports on everything under the subcontinental sun. "Collections" and "returns" poured off the government presses, flooding the official channels of communication with data on harvests, village boundaries, flora and fauna, and native customs. Everything was surveyed, mapped, classified, and counted, including human beings, who appeared in the first Indian census in 1872, divided neatly into castes, subcastes, and a dozen other categories determined by the columns of a printed form. The catalogues of books belonged to this effort to catalogue everything. They constituted a census of Indian literature as the Imperial authorities understood it. ${ }^{7}$

Foucault's knowledge/power formula fits the later phase of British rule in India and helps explain the catalogues of books, but it is far too facile. Many rulers genuinely cared for the welfare of the natives. Lord William Bentinck, GovernorGeneral from 1828 to 1835 , did not simply seek to maximize power by abolishing sati or even by admitting Indians to the East India Company. Nor did his advisor, Thomas Babington Macaulay, design an educational system to be conducted in English for an Indian elite merely in order to make the bureaucracy more efficient. They believed in the liberal principle of promoting happiness. In fact, the father and grandfather of liberalism, John Stuart Mill and James Mill, developed that principle into a philosophy while working for the East India Company. J.S. Mill's testimony about the Company to the House of Lords in 1852 anticipated his manifesto of liberalism, 
On Liberty (1859). And Mill's biographer, John Morley, tried to translate that philosophy into government policy fifty years later while serving as Secretary of State for India.

True, Morley found it impossible to reconcile his commitment to freedom of the press with his need to repress nationalist agitation, and insofar as utilitarianism provided imperialism with an ideology, it strengthened the Raj. In developing "utilities" such as railroads, telegraph lines, and the postal service, the British consolidated their control of the subcontinent. But they also provided irrigation works, police protection and justice, British style. District magistrates often took the side of peasants against landlords, even though they did not upset indigenous hierarchies. Unlike the rapacious adventurers of the eighteenth century, they subscribed to an ethos of hard work and service. They took up the white man's burden in earnest. And despite the growth of racism, some symbiosis developed between foreign and indigenous elites. As English education spread and Indians worked their way into administrative bureaucracies and the professions, an Indian intelligentsia took root. The result was not simply the much maligned babu (the Anglicized Indian clerk or official) but also the Bengal Renaissance. After the foundation of the Brahmo Samaj (Society of Brahma) in 1828 by Ram Mohun Roy, who began his career as an assistant collector in the East India Company, Indian intellectuals began to work ingredients from their ancient classics into an original variety of modern literature, and they found inspiration in Shakespeare as well as the Upanishads. At a humbler level, babus in the bureaucracies, thousands of them, filled in the forms and drafted the reports that shaped the Raj's understanding of itself. They helped create British India as a cultural construct, Orientalism and all. That was a complex process, visited on the Indians by the British and executed in large part by the Indians themselves, and there is no better site on which to study its elaboration than column sixteen of the Raj's catalogues of books. ${ }^{8}$

Column sixteen was not added to the standard form until August 1871; and the first librarians to use it kept their comments to a minimum, though they did not hesitate to pronounce judgment on the books they registered: "miscellaneous songs, chiefly of a filthy character;" "a description of the first amorous dalliances of Radha and Krishnu, altogether a filthy book;" "a Hindoo mythological tale. The filthiest poetical effusion imaginable;" "pieces of poetry on different subjects, professedly written for, but not at all suited to boys."

After this initial stage of culture shock, the confrontation of the Victorian with the Bengali imagination in column sixteen produced increasingly complicated reactions, and the "remarks" grew apace. Soon they spilled over the neatly ruled lines between the columns, invading the neighboring space, running across the page, filling the whole sheet with a flood of words. By 1875, column sixteen began to read like the column of a journal, and the remarks turned into reviews. William Lawler's opinionated comments were typical of the genre. In fact, his opinions did not differ markedly from those of the other librarians, Indians included. The babus_displaced the British in 1879, when Chunder Nath Bose succeeded Lawler. ${ }^{10}$ From then on the catalogue was compiled by Indians, aided no doubt by assistants, for no individual could keep up with the literature streaming from the presses in the late nineteenth and early twentieth centuries. But the tone of the remarks remained essentially the same, though the Indian librarians seemed to be less obsessed with sex and more concerned with philological correctness. When they detected signs of restlessness among the "natives", they sounded just as concerned or indignant as their British predecessors. Chunder Nath Bose deplored a Bengali novel, Surendra-Binodini Natak: "The story 
of love is mixed up with another story, the object of which seems to be to excite in the native mind a strong hatred for English rule and the English character. There are passages in which the author's language becomes almost seditious." 11 Should this continuity in the commentaries be taken as a symptom of cooptation, Anglicization, or self-imposed Orientalism? It is difficult to say, given the lack of information about the librarians. But one characteristic stands out: their linguistic virtuosity. Harinath De, a candidate for the post of Imperial Librarian in Calcutta in 1906, had mastered Latin, Greek, German, French, Italian, Spanish, Sanskrit, Pali, Arabic, Persian, Urdu, Hindi, Bengali, Uriya, Marathi, and Guzerati, along with some Provençal, Portugese, Romanian, Dutch, Danish, Anglo-Saxon, Old and Middle High German, and a smattering of Hebrew, Turkish, and Chinese. He got the job. ${ }^{12}$

What tendencies emerge from thirty years of these running comments on the daily output of books? First, ethnographic bewilderment. To the British librarians in the 1870 s, Bengali literature was a strange assortment of incompatible elements. Thus Gyananjan or Pigment of Knowledge: "...Miscellaneous verses on time, hope, rich men, the quail and cocoanuts." 13 The incomprehension went both ways, for the remarks in column sixteen also provide glimpses of the Indians observing the British. A popular Bengali compendium of advice and useful knowledge included little essays on the following subjects, according to William Lawler's synthesis: “...Toil, sleep, health, fish, salt, indigo, and the pig, which is described as a filthy animal, the flesh whereof is eaten by the lowest class, such as sweepers, domes, mehters, and also by Englishmen."14 In fact, no vernacular literature expressed a state of anthropological purity untouched by the imperialist presence. Indians and Britons had been forming British India for more than a century before the catalogues began to record the British understanding of the Indians' understanding of their common world.

It required a considerable ethnographic effort, nonetheless, for the British to get their bearings in the alien literature. They often came up against pages that remained entirely opaque. Thus Chinta Lahari, or Waves of Meditation as read by John Robinson in 1878: "A piece of incoherent and unintelligible writing. A few lines of poetry, a few songs, and some dialogues, all pointless. It is not clear why the author should have taken trouble to write so much nonsense." 15 The remarks take on a less tendentious tone in the later catalogues, no doubt as a result of the Indian librarians' attempts to act as intermediaries, translating and negotiating differences between cultures. But the early catalogues do not generally condemn native folkways. They describe village medicine, magic, domestic life, religious rituals, and even polygamy in a fairly straightforward manner, although they contain enough remarks about Indian "idolatry" to remind the reader where truth is located. ${ }^{16}$ When it came to the supernatural, the British showed a preference for beneficent deities like Satya Pir, who was worshipped with offerings of flowers and milk by the Muslims of Eastern Bengal, in contrast to Kali, the terrible Hindu goddess of destruction, who had to be appeased with bloody sacrifices of goats. ${ }^{17}$ The mystical and poetical qualities of Hinduism appealed to them. They expressed admiration for the depth of the Vedanta and the pathos of the Ramayana, although they complained about impenetrable obscurities; and when they effused about poetry, they made it sound like English romanticism. Thus "the lament of a widowed lover" in Nibhrita Nivas Kavya or The Lonely Habitation: "The description of the earth and other planets as beheld by the spirit of the heroine, beautiful and chaste, in its ascent heavenwards in company with celestial nymphs, is thoroughly poetical. There is considerable similarity between it and certain passages in Shelley's Queen Mab." 
Popular Bengali literature, by contrast, received nothing but scorn in the catalogues. The librarians dismissed it as cheap stuff, "street literature" flogged by peddlers among the poor of Calcutta and the ignorant villagers of the mofussil (hinterland). It dealt in urban horrors--low-life, murders, detectives, prostitutes--and rural fantasies--fairies, magic, adventures, astrology. Judging from the remarks, it was somewhat similar to the penny dreadfuls and chapbooks of contemporary Europe. But its sentimental romances drew on Hindu mythology and its almanacs combined astrological advice with mantras to be recited while boring ears or giving a child rice for the first time. ${ }^{19}$ Song books also circulated widely, mixing traditional ribaldry with comments on current events. And most important of all, printed versions of popular plays, usually small booklets but sometimes volumes of 200 pages or more, spread the spicy fare of Calcutta's theaters throughout the entire province. All this printed matter was read aloud, in workplaces, bazaars, and the domestic quarters of women; and the readings were performances, some by professionals, who sang or acted out the texts, bringing them alive before a vast audience--roughly two million in 1857 in Bengal alone, according to one, well-informed source. ${ }^{20}$

The keepers of the catalogues did not waste space by commenting extensively on this ephemera, but they summarized its contents in a way that would inform the British reader about Oriental exoticism. Thus Sarbbagyan Gyanmanjari or The Blossoms of All Knowledge: "Astrology or commonplace fortune telling, including the Hanuman Charita, the Kak Charita (signs and omens by the noise of crows) and Spandan Charita, by the spasmodic action and motion of the veins, eyes, and nerves." 21 Column sixteen contained many précis of the plots of plays such as Rajatgiri Nandini Natak or The Daughter of the Golden Mountain Crest:

The son of Joubanashya, Raja of Pingal, fell in love with Khyanaprabha, daughter of the king of Rajatgiri, a fairy, and eventually married her; but an astrologer, who was the enemy of the prince, managed, by his machinations, to have the heroine exiled. Ultimately, however, she is sought after by, and rejoined to, her husband, and the wicked astrologer meets with his deserts by being killed. $^{22}$

Put so baldly, the plot seemed to suggest that the "natives" amused themselves by fairy tales, like children. In the case of drama derived from religious literature, the remarks sounded less condescending. "The plot is taken from the Ramayana, and has often been noted in previous catalogues in extenso," observed William Lawler in 1879. "The natives seem to have a great predilection for those dramas adapted from the Ramayana, which are always acted with much spirit." 23 By 1900, however, the religious element in pulp fiction seemed to be receding before the advance of Western influences, including sentimental melodramas about unrequited love and the evils of drink. ${ }^{24}$ Crime stories published in booklets to advertise hair oil made Calcutta look vaguely like dockside London, minus the cold and fog. ${ }^{25}$ To the keepers of the catalogue, it was all rather distressing, a symptom of a new plebeian culture grafting itself onto a venerable, ancient civilization. A typical remark deplored a popular drama in 1900 as "a low-class farce....It is a vulgar production and does not call for further notice." 26

Column sixteen does contain some admiring remarks about serious Bengali fiction. Rabindranath Tagore received complimentary notices long before he was awarded the Nobel Prize in $1913 .{ }^{27}$ The catalogue hailed Swarmalata in 1881 as 
"perhaps the only novel (as distinguished from a romance or a poetical tale) yet written in Bengali." ${ }^{28}$ It noted the influence of Brahmoism ${ }^{29}$, the spread of literary reviews ${ }^{30}$, and the appearance of occasional volumes of poetry "inspired by genuine feeling and an appreciation of the beauties of nature." 31 Individual authors stand out, like Ishvarchandra Vidyasagar. ${ }^{32}$ But the "Bengal Renaissance" is never mentioned. Far from indicating any awareness of a general blossoming of modern literature, the catalogues leave an impression of a few good books bobbing about in a rising tide of vulgarity.

The main quality that commanded respect throughout the catalogues was philological prowess. Having received a double dose of education in the classics-Sanskrit and Persian on top of Greek and Latin--the librarians were quick to condemn faulty translations and impure language. They reserved their highest praise for treatises like Bhasha Tattva or Truths of Language: "The chapter on the deduction of Bengali case sufffixes and verbal forms from Sanskrit discloses a true philological insight." 33 In reviewing fiction, they gave high marks for correct language and a traditional style. Thus Udvaha Chandraloka or The Moonlight of Marriage: "The book is written in pure, idiomatic Sanskrit, which very few pandits, if any, can write in these days. The metrical introduction...will be found to be of great value. The work is in every way worthy of the deep and varied scholarship of its author." ${ }^{34}$ A proportionate degree of scorn fell on anything "low" and "vulgar" in style as well as subject matter. The cataloguers favored "Sanskritic" Bengali over "Mohammedan" Bengali, and they were especially severe when they came upon infelicitous writing. A full-scale review of a novel, Gajimiyar Bastani or Gajimiyan's Bundle, concluded: "The writer, though a Mahommedan, writes Bengali with ease and possesses a wonderful command over the vocabulary of the language. But his style is nevertheless ungrammatical and marked by East Bengalism and an absence of literary grace. " 35 The keepers of the catalogues acted as guardians of the flame of culture, the Indian equivalent of the golden age of Greece. They identified civilization with Sanskritization, or what they took to be a cultural strain that led back to an ancient world of classical purity. That, too, belonged to the Raj constructed jointly by the British and the Indians.

Nothing would seem to be further from political control than an obsession with literary style, but literature under the Raj was political in itself, down to its very syntax. ${ }^{36}$ By adopting a Brahmanic view of Indian culture, the British reinforced their basic policy after 1857: leave the indigenous hierarchies in place and rule through the elite. At the same time, they used their surveillance of vernacular literature as a way to watch for signs of danger. When they sifted through poetry, they looked for symptoms of discontent among the "natives" as well as deviation from puranic purity. A reviewer dismissed a collection of 34 Bengali poems as "of not much importance"-all except for one:

There is one poem, however, on the lament of India, wherein the abject and totally dependent state of the natives is brought out. The Briton is pictured as riding about in his conveyance, whilst music plays to the tune of "Rule Britannia"...The natives are described as trembling with fear at the sight of a white man. The loss of independence of the natives and the departure for ever of their good and noble countrymen are deplored. ${ }^{37}$ 
The cataloguers paid special attention to plays, where they picked up a steady stream of comments on current events. Spectacular trials like the Baroda case of 1876 provided Bengali playwrights with plenty of material to condemn British justice, personified by a standard cast of villains: tyrannical judges, vicious policemen, and sadistic jailers. ${ }^{38}$ By dramatizing miscarriages of justice, the plays made the whole regime look evil; and in some cases, they also attacked social injustices, including the exploitation of peasants by landlords. ${ }^{39}$ Behind the landlord loomed the figure of the district magistrate and even the missionary, both of them complicit in the basic task of draining India of its wealth and oppressing its people. A long review of a drama from 1878 concluded:

The work embraces a variety of topics, such for instance as the utter hypocrisy of many Christian missionaries who, while ostensibly engaged in the work of preaching the Gospel, treat the natives of the country in a most cruel manner and do not shrink even on the slightest provocation to murder them. Their style of preaching, their pronunciation of the Bengali, the abuse they pour upon Hindu gods and goddesses and the wicked and hypocritical character of the native Christian converts are all powerfully satirized. The writer throws much ridicule on the manner in which trials of Europeans accused of murdering natives are conducted in the law courts. How a European beats to death an inoffensive native servant, for instance; how his widow and children are paid a few rupees as compensation for the loss of their guardian; how suborned witnesses are procured....It is an altogether mischievous production, calculated to foster discontent and mislead ignorant people. ${ }^{40}$

It would be possible to string together enough quotations of that sort to suggest that British India was seething with sedition. In fact, however, the great majority of the comments in column sixteen made no direct reference to politics; and when they did register signs of restlessness among the "natives", they did not sound particularly worried. Their tone remained matter-of-fact, as if the Indians could be left to let off steam while the British got on with the business of government. ${ }^{41}$ Moreover, the Indian publications also expressed a strong counter-current of support for British rule. Poems celebrated such unlikely subjects as the construction of waterworks:

The author at first portrays in glowing language the many and lasting benefits conferred on the people of this country by the British government, and then describes such things as watches, coal, gas light, the mint, telegraph, railway, water-works, engine-made paper, the Asiatic Society, etc., all introduced or established by the English. The poetry of the book is pretty good. ${ }^{42}$

The visit of the Prince of Wales and Queen Victoria's assumption of the title Empress of India in 1876 produced bursts of poetical effusion, some of which hailed the British for liberating Indians from "the Mohammedan yoke and oppression," a fairly common theme in Hindu writing. ${ }^{43}$ A few tracts contrasted the "Indian character" unfavorably with "the genius of the British." " In 1900, one went so far as to urge the Indians to "...work more and talk less," avoiding all kinds of agitation in order to win 
the respect of their rulers. ${ }^{45}$ Whether such sentiments were genuine or were a mixture of propaganda and sycophancy cannot be determined from the catalogues, but they occurred often enough to suggest that the British thought they had plenty of support among the literate elite. ${ }^{46}$

Discontent showed through nonetheless, not usually in the form of open opposition to British rule but rather in the themes of humiliation and oppression, which the cataloguers found everywhere by the end of the nineteenth century, even in plays and poems that sang the praises of the Raj. That such contradictions could coexist in the same body of literature may seem seem odd. Perhaps they are merely an optical illusion, produced by looking at that literature through a double filter: the historian studying the imperialists studying the texts. But contradictions were built into the core of imperialist culture. Seen through the catalogues, Indian literature in the nineteenth century combined self-hatred with hatred of the foreigner and selfassertion with deference to the sahib.

The contradictions derived in part from a cyclical view of history, in which golden ages of expansion gave way to iron ages of decline. The most golden of all took place in the remote past, when the Aryan people built a great civilization on the territory they conquered from 1500 to 450 B.C. The most decadent age began with the Mughal invasion of the sixteenth century and reached its nadir in the present, with the British Raj. Because the gods presided over this process, history shaded off into mythology. Lord Shiva, the god who had favored the Aryans, gave way to Kali, the goddess of destruction, whose ascendance made for misery in the current age of iron. Famine, plague, and poverty left the common people prostrate before the feringis (foreigners). Instead of seizing lathis (a long, iron-bound club) and rallying against the conquerors, the elite adopted their ways. Everywhere, especially in Calcutta, babus_were speaking feringi language, drinking feringi alcohol, and collecting the feringis' taxes. Some married without their parents' consent. Some even married widows! A sense of shame and decadence spread throughout the literature, accompanied by protests against foreign domination. "Young Bengal" became a favorite target of popular plays, printed as booklets, which adapted traditional themes to current events. Sura-sanmilana, or The Assembly of the Demi-Gods seemed "full of import" to a cataloguer in 1879 :

It represents a meeting or darbar held in the presence of the three principal gods embodying the Hindu Trinity, with ten crores or thirty millions of the demi-gods as members to consider in committee the impending famine of 1268 B.S., or 1879 A.D. Lord Lytton [the current Viceroy], as Indra, the king of the gods, is to blame for all this, who attends to nothing else but fun and sport and theatrical entertainments, living in the midst of luxury and all that is desirable for life. He, however, exonerates himself by blaming the depravity of the times, especially among the natives, in this Kali or iron age--the prevalence of lying, lust, drink, etc. Sir Ashley Eden [then governor of Bengal] excuses himself in the person of Varuna, or the Indian Neptune, by saying that he has simply to obey and carry out orders, and has no will of his own in the matter. The alleged culprits are pardoned with a warning to take care that such things do not occur again in future. The names of the Viceroy and His Honor are not openly used, but the facts become evident from the tenor of the play. ${ }^{47}$ 
To be sure, some works, especially in new genres like the novel, were derived from Western models and celebrated the babu himself as a model of modernity. ${ }^{48}$ But the most popular genres, above all drama, made the babu into a symbol of the deplorable effects of Westernization. In 1871, a typical farce turned on the theme "that the civilization of Young Bengal consists in eating meat and getting dead drunk." $" 49$ By 1900, the Anglicized Indian had become a stock figure of traditional farces, used not merely to raise a laugh but to protest against British rule. ${ }^{50}$ Poems and songs struck a common chord of indignation. ${ }^{51}$ In a typical poem, "The Aryan race is upbraided and asked how the Britons, a nation of shopkeepers, could venture to sit on the Delhi throne?"52 Everywhere the ancient Aryans served as a rebuke to the degradation of their descendants. ${ }^{53}$ To imitate the Aryans was to caste off Western manners and to become more manly, more militant, and (at least in nonMuslim Bengali literature) more Hindu. ${ }^{54}$ All these themes, as the librarians patiently culled through them and entered them in the catalogues, expressed a spirit, not merely of discontent but of passionate nationalism. At their most vociferous, they sounded like a summons to rise in revolution:

The Bengali is called a coward and taunted with being so accustomed to the chains of slavery, and so delighted with it, as to forget the very name and meaning of "independence." The poet reminds his countrymen of their noble ancestors and their valorous deeds; describes "independence" as a precious jewel, the very sound of the name of which gives life to the dead; also that the Americans esteemed it so great a treasure as to have flown to arms with one accord to preserve it. $^{55}$

How serious were these symptoms? To put them in perspective and to get an impression of more general tendencies, one can aggregate statistics from the annual reports submitted by the provincial governments after $1874 .{ }^{56}$ The statistics were compiled by the Indian Civil Service from the material in the catalogues, so they are even further removed from what anthropologists sometimes call "the natives' point of view." But they show that the printed word was carrying vernacular literatures to a reading-hearing public on a vast scale throughout the subcontinent. The pattern varied from place to place, and it was shaped by the categories that the ICS used to classify the catalogue entries; so it had little to do with indigenous conceptions. "Art", "biography," "history", and "travel" probably would not have demarcated distinct genres to most Indian readers, who also would have lumped together much of the material that the British classified separately as "religion", "philosophy," and "poetry." "Language" referred overwhelmingly to dictionaries, grammars, and school books. "Religion", the largest category everywhere, covered a huge range of material, in contrast to "fiction", which was relatively weak, despite the advent of Europeantype novels. And "miscellaneous" left room for all sorts of popular genres: astrology, divination, proverbs, tricks, charms, advice, agricultural information, and essays on socio-ethical issues such as widow-marriage. Arbitrary as they are, however, the statistical tables provide an overview of book production as the British understood it. The following table summarizes the reports for 1898 from the three largest presidencies - Bengal, Bombay, and Madras - and, as an example of a remoter 
region, the Northwestern Provinces and Oudh. ${ }^{57}$ It can be taken as a snapshot of one year of Indian literature, even though it tells more about the beholders than the books:

[Table for 1898 goes here]

Without going into a detailed analysis, I think the table illustrates the scale both of Indian production and of the British effort to keep track of it. Lawler and his successors noted the publication of several radical tracts. But by 1900, those books produced only a few ripples in a vast ocean of literature that looked conventional and calm. In its overwhelming mass, it consisted of ancient classics, devotional works, religious poetry, mythological tales, professional manuals, textbooks, almanacs, and cheap, popular fiction. True, some books were never submitted for registration. The proportion could have been as high as 25 per cent in Bengal, according to the report produced in Calcutta in $1898 .^{58}$ But the uncatalogued works were mainly ephemeral chapbooks and "bazaar trash" in the view of the cataloguers. ${ }^{59}$ After 1900, a few antiimperialist works arrived in the mail from abroad, and others were produced in foreign enclaves like Pondicherry and Serampore. But India did not develop an elaborate underground literature comparable to that of pre-revolutionary France or Communist Eastern Europe. ${ }^{60}$ On the contrary, the government permitted the publication of books that seemed openly seditious to the men who registered them. The remarks in the catalogues and the reports to the lieutenant governors show that the ICS picked up potentially disturbing signals without becoming disturbed. The "natives" might be restive, but the British believed they had things well in hand.

Being British for many of the colonial administrators meant respecting a "native" tradition of their own: freedom of the press. After the expiration of the Licensing Act in 1695, prepublication censorship ceased to exist in England, and postpublication sanctions could be applied only through the courts, by means of prosecution for sedition and libel. In India, it is true, the authorities often banned newspapers, especially independent-minded English-language newspapers like The Bengalee, which sometimes printed nasty things about governors and magistrates. In 1878 they imposed restrictions on the vernacular press by a "gagging act" (the Vernacular Press Act), which was intended to stifle criticism of the Second Afghan War. It set off vehement protests among the Indians, because it suggested that freedom of the press existed only on one side of the line that divided Britons from "natives." But the act was repealed in 1880, when Lord Ripon succeeded Lord Lytton as viceroy in Calcutta and Gladstone replaced Disraeli as prime minister in London. The Liberal governments genuinely believed in free trade in ideas. They followed the policies developed by Mill and Macaulay, as if liberalism and imperialism were natural allies. ${ }^{61}$

There were exceptions, of course. The most famous was the Nil Darpan affair of 1861 in which James Long, an English missionary and a remarkable amateur ethnographer, was condemned for distributing an English translation of a Bengali drama which attacked the indigo planters for exploiting their peasants. ${ }^{62}$ But the catalogues reviewed many equally outspoken plays, which were performed and published without incident; and the Dramatic Performances Act of 1876 was as ineffective against the theatre as the Vernacular Press Act was against the newspaper 
press. When it came to books, the surveillance remained anodyne. It took the form of endless reports by harmless librarians, many of them Sanskrit scholars, who picked through a mountain of publications, much of it "bazaar trash," as they saw it, in obedience to the directives of a bureaucracy with an insatiable appetite for information.

If examined a century later, however, after two world wars and countless colonial upheavals, the information looks more ominous than it did at the height of the Raj. It exposed an explosive passion: nationalism. As long as the contradiction between imperialism and liberalism remained latent, that passion could be contained. But when imperialism showed itself to be rule by right of conquest and when the printed word began to penetrate deeply into Indian society, the nationalists aroused a response, books became dangerous, and the Raj resorted to repression. Before 1900, the record seems to bear out the imperialists' conviction that they treated Indian literature liberally: Britannia ruled and the press remained free, free even to lament the country's lack of independence. Afterward, things began to fall apart. The event that opened up the contradiction at the heart of the Raj took place in 1905: the partition of Bengal.

Of course, Bengal was not India. The Indian National Congress first met in Bombay in 1885, and nationalists first turned to terrorism in the Bombay presidency, where Balwantrao Gangadhar Tilak whipped up the passions of Marathi-speaking Hindus with his newspaper, Kesari. Groups of nationalist intellectuals also formed around newspapers in Madras (the Mahajana Sabha) and in Lahore (The Punjabee). But Calcutta, the capital of Indian literary life as well as of the British administration, provided the most fertile soil for agitation. Nationalism took root among its bhadralok, a large population of professional people, minor bureaucrats, and rentiers, who felt the pinch at the turn of the century, when the economy slumped and access to careers closed up. By 1905 young men from this milieu had been stirred by the Bengal Renaissance and the Hindu revival. Angry, articulate, overeducated and underemployed, they warmed to the cult of Shivaji, the Maratha warrior who overthrew the Mughals in the seventeenth century; and they took fire when exposed to novels like Yugantar by Sibnath Sastri and Kali, the Mother by Sister Nivedita (Margaret E. Noble.) They also thrilled to reports of heroic self-sacrifice and nationalist agitation among the Carbonari, the Decembrists, the Italian Red Shirts, the Irish republicans, the Russian anarchists, and the Japanese soldiers, who showed that Asians could defeat Europeans in the Russo-Japanese War of 1904-1905. The partition of Bengal, proposed by the Viceroy Lord Curzon in 1903 and executed in October 1905, gave them a life-and-death cause in their own back yard. ${ }^{63}$

To the British, the partition made good, solid, bureaucratic sense. Bengal was a vast province of 189,000 square miles with a population of 80 million, more than twice that of Britain, and it could not be administered adequately by a lieutenantgovernor and a scattering of district officers. But to the Bengalis, the partition was a murderous blow, which cut deep into the flesh of their body politic. They attributed it to a cynical strategy of divide and rule: the new province of Eastern Bengal and Assam would provide the British with a docile Muslim dependency, while the bhadralok intellectuals of Calcutta would lose influence relative to the non-Bengali speakers of West Bengal. Speeches, petitions, protests meetings, demonstrations, loud choruses of the new nationalist anthem Bande Mataram ("Hail to Thee, Mother"-ie. India) fell on deaf ears. Curzon was as unbending as the steel brace that he wore to support his back. And Lord Minto, who succeeded him as viceroy in 1905, showed even less concern for the wishes of the native population, despite the prodding of his 
superior, John Morley, the Secretary of State for India in London. Morley was a devout Liberal and biographer of Gladstone, who took office with the Liberal government elected at the end of 1905. He favored all sorts of reforms, including the election of Indians to provincial councils; but when he acknowledged the partition of Bengal as a "settled fact," the Bengali intellectuals felt betrayed by the very principles that they had imbibed in their English schools.

After the failure of "mendicancy"--the policy of cooperation favored by the moderate wing of the Congress Party--the nationalists took to swadeshi, a strategy of boycotting British imports and favoring home-made goods. The boycott of manufactures led to the boycott of institutions--courts, schools, the civil service--and the demand for swaraj (self-rule, independence). Groups of militants drew on revivalist Hinduism in order to develop alternative forms of civic life, such as the ashram (rural retreat) and the samiti (an assembly or committee of an association). They founded schools, where they drilled young men in "lathi play," or the use of the traditional sword-staff, and sometimes indulged in wild talk of enforcing the boycott through violence and of resorting to political banditry (dacoity or gang robbery). The agitation became directed against the Muslims as well as the British, because the huge Muslim minority, 30 per cent of the population in Calcutta itself, remained untouched by the Hindu revival and unmoved, in most cases, by the boycott. The creation of the All-India Muslim League, with Minto's encouragement, at the end of 1906 confirmed the view that the British were playing a game of divide and rule. Hindu-Muslim riots at Comilla and Mymensingh in the spring of 1907 drove a wedge between the two populations. Under the pretext of restoring order, the British suspended civil liberties and began arresting agitators everywhere from Bengal to the Punjab. But the Hindus themselves split when the Congress Party broke up at its annual meeting in December 1907. And the extremists found themselves increasingly isolated--unable to work with the old, moderate political elite, on the one hand, and incapable of mobilizing the impoverished, illiterate peasant masses, on the other.

Trapped in this impasse, the most radical nationalists tried to blast their way out by means of bombs. The examples of European anarchists, the notion of propaganda of the deed, the appeal of heroic self-sacrifice, and the cult of Kali also reinforced the turn to terrorism. On April 30, 1908 a bomb killed two British women in a railway car at Muzaffarpur. The investigation led to a raid on a terrorist group in Maniktala, a suburb of Calcutta. After one of the group incriminated the others and exposed their entire operation, he was assassinated in the Alipore jail by two more terrorists in August. A sub-inspector of police and a public prosecutor were murdered in November. In July, 1909, a Punjabi extremist assassinated Morley's aid, Sir William Curzon-Wyllie, in London. The terrorists also made attempts on the lives of Minto and one of his aids, Sir Andrew Fraser, but they failed to blow the British administration off course and to spark an uprising of the peasants. The cycle of violence came to an end with an unsuccessful attempt on the life of Minto's successor, Lord Hardinge in 1912. By then, most of the extremists had been arrested or driven out of the country. The transfer of the capital to Delhi and the reunification of Bengal in 1911, followed by the outbreak of World War I, put an end to this first phase of nationalist agitation. In retrospect, it seems clear that the partition protests and the terrorist campaign never constituted a serious threat to the Raj. But they looked terribly threatening between 1904 and 1912, when the British kept reminding themselves that they were an alien population of a few hundred thousand trying to rule a subcontinent of several hundred million while preaching the virtues of freedom from arbitrary arrest and freedom of the press. 
The press had fueled the explosion of nationalism from the very beginning. The leading agitators were men of letters, who drew their inspiration from literature, both Indian and Western, and gathered around newspapers and libraries. Calcutta's most important nationalist circle, the Anushilan Samiti, had a library of 4,000 volumes, and its revolutionary weekly, Yugantar, which mixed belles-lettres with calls for revolutionary action, took its name from the novel by Sibnath Sastri. Songs, plays, poems, pamphlets, religious tracts, histories, literature of every variety turned up wherever a British agent discovered signs of sedition. The servants of the Raj knew this literature very well, because they had been keeping track of it for forty years in their catalogues and reports. After 1905 the question was: How could they use this information to repress the outbreak of nationalism?

At this point surveillance turned into punishment. It took two forms: repression by the police and prosecution in the courts.

The police action resembled that of authoritarian regimes everywhere. It involved raids on bookshops; interrogation and intimidation of suspects; the arrest of authors, publishers, and printers; the interception of letters and packages in the mail; even the use of secret agents to report on what was said in meetings and what was read in schools. As accounts of this activity began to churn through the vast digestive tract of the India Civil Service, it became clear that the literature now deemed to be seditious was the same as the literature that had appeared for years in the catalogues. It covered the same spectrum of themes and genres and included many of the same books, but now the agents of the Raj wanted to annihilate it, whatever the cost might be in the loss of civil liberties. "Summary procedures" were necessary, according to the lieutenant-governor of the Punjab, for the "natives" were "credulous", "emotional", "inflammable" and liable to explode when provoked by seditious messages. ${ }^{64}$ Only "autocratic government" could keep the "diverse races" of India in check, according to the lieutenant-governor of Burma: all dubious publications must be eradicated, but with as little fuss as possible so that no one in Britain would hear about it. ${ }^{65}$ In the Central Provinces, one commissioner worried about protests from "Sir Henry Cotton and Company and other misguided politicians in England." another recommended severe repression: "The gravity of the situation demands that we take whatever is absolutely the most effective measure for controlling sedition in the press without regard to any Western theories or sentiments, which are not applicable to the condition of this country." ${ }^{\circ 7}$ Everywhere the men in the field seemed to regard freedom of expression as a Western luxury that would make government impossible in India. ${ }^{68}$ Lord Minto pressed their views on Morley, demanding arbitrary power to curb the press. ${ }^{69}$ But the liberty of the press belonged to the most sacred articles in Morley's Liberal creed; and the disparity between preaching liberalism and practising imperialism stood out every week during question time in Parliament, when back-benchers like Sir Henry Cotton, a well-informed expert on Indian affairs, exposed the illiberalism of British rule in India for all the world to see. ${ }^{70}$

While Minto and Morley dueled in their dispatches, the humbler agents of the Raj filled the confidential correspondence of the ICS with reports of repression. In one raid on a nationalist association, the books confiscated by the police included Aristotle's Politics, as well as English-language works such as The Awakening of Japan, and The Life and Writing of Joseph Mazzini. ${ }^{71}$ To print, without comment, accounts of nationalist movements in Ireland and Italy seemed subversive to officials in Bombay: "Government are teaching the ryot [peasant] to read, and unless 
Government see that the ryot is provided with wholesome matter to read, he must inevitably become the prey of the purveyor of literary poison., ${ }^{, 72}$ The Raj officials would not permit the import of a book of excerpts from official documents printed by the government in London, because it made the Indian police look bad. ${ }^{73}$ Postal inspectors often seized The Gaelic American and anti-imperialist speeches of William Jennings Bryan in the mail. Bryan, translated into Indian languages, seemed especially threatening to the Criminal Investigation Department: "The ignorant Hindu reader imagines that Bryan is qualified to criticize, and that he is English instead of being what he is--an American demagogue and openly hostile to England." 74 The officials hesitated to condemn a book by the fiery Punjabi nationalist, Ajit Singh, in which he simply strung together short biographies of great patriots, from Brutus to Robert Bruce, John Hampden, and Samuel Adams. ${ }^{75}$ But they planned to prosecute a publisher for reprinting some speeches by Balwantrao Gangadhar Tilak, which had been permitted at the end of the nineteenth century. They also saw sedition in a reprint of a hostile history of the East India Company by William Howitt, which was first published in 1838 and had been available in several public libraries ever since. In a brief for the prosecution, a legal advisor to the government did not dispute the accuracy or the age of the text. Instead, sounding more like a modern reception theorist than an agent of the Raj, he argued that it had taken on new meaning. An unsophisticated reader of the cheap, modern, Urdu edition might believe that the criticism made in 1838 applied to the Raj in 1909. "It is the effect on the general reader that must be considered," he insisted. And as a clincher to his argument, he noted, "The legislature has decreed that the reputation of the present Government of India shall be sacred." The advocate-general of the Government of India concurred: "What some years back would have been innocent matter is today dangerous." The same arguments applied to other books, which had been duly registered in the catalogues without arousing charges of sedition. ${ }^{77}$ The literary landscape remained the same as it had been before 1905, but it looked entirely different.

Having executed this Gestalt-switch and filled its jails with arrested authors, the agents of the Raj needed to get them convicted in court. This last step was the most difficult of all, because it threatened to expose the contradiction inherent in liberal imperialism. The British were committed to play by the rules that they had imposed upon the Indians. They believed in those rules--the rule of justice first of all-as the measure of the civilization they had brought to the subcontinent. So they accepted the right of Indians to publish books under the same constraints that applied to Englishmen--that is, freely, subject to the laws of libel and sedition. To be sure, sedition had acquired a peculiar meaning under the Raj. According to Section 124A of the Indian Penal Code of 1860, written in the confusion of the post-Mutiny era, it applied to anyone who "excites or attempts to excite feelings of disaffection to the Government." ${ }^{, 78}$ Disaffection remained undefined until 1897, when a court in Poona condemned Tilak, the most influential nationalist at the turn of the century, to eighteen months of rigorous imprisonment for an article he had published in his newspaper Kesari. Infuriated by the government's failure to take adequate measures during the bubonic plague of 1896, he had cited the Bhagavad Gita as justification for the murder of a Mughal general by Shivaji during a desperate moment in 1659. Some days later, one of Tilak's followers murdered a British official. The judge found Tilak guilty of sedition under Section 124A, setting a precedent for dozens of cases tried during the agitation after the partition of Bengal. Tilak himself was tried and convicted again in 1908, this time with a sentence of transportation for six years to a prison in Mandalay. ${ }^{79}$ 
By then the government had passed new legislation to strengthen its hand in the courts. An Indian Penal Code Amendment Act of 1898 reaffirmed the catch-all character of Section 124A with some additional language, which was vaguer than ever: "The expression 'disaffection' includes disloyalty and all feelings of enmity.", 80 An Indian Criminal Law Amendment Act of 1908 did away with trial by jury in certain cases of sedition. A Newspapers Act, also passed in 1908, empowered district magistrates to seize presses of papers they deemed to be seditious. And an Indian Press Act of 1910 required all owners of presses to deposit security and authorized magistrates to confiscate both the money and the presses in order to stop disaffection "both by openly seditious writing and by suggestion and veiled incitement to inculcate hostility to British rule." ${ }^{81}$ These measures applied to all publications, books and pamphlets as well as newspapers, and authorized searches of the mail and of bookshops in addition to printing shops. Because a Dramatic Performances Act of 1876 had given district magistrates even broader powers to prevent productions of plays, nearly all the media had become subject to arbitrary action by the authorities. ${ }^{82}$ It merely remained for the judges and lawyers to put on convincing performances in the courtrooms.

In retrospect, the verdicts look like foregone conclusions. Judges outraged by terrorist incidents were not likely to be lenient. Most of the authors were convicted and sentenced to "rigorous imprisonment," usually for terms of one to six years, sometimes with an additional punishment of a heavy fine and "transportation" to a sweltering prison in Mandalay. To make the sentences carry weight, however, the judges, lawyers, clerks, and bailiffs had to play their parts effectively. The wigs and robes, the gaveling and taking of oaths, the standing up and sitting down, the legalistic language and formalistic courtesies--"Your Honor", "the Learned Pleader"-demonstrated the legitimacy of British law in an Indian setting. But the Indians had learned to play that game, too. Their pleaders had studied in British schools and could defend their clients by citing British precedents--or, if need be, Shakespeare and Milton. Of course, most citations tended to come from the Mahabharata and the Ramayana, for that is where the accused writers drew their inspiration. To win their case, the prosecutors had to argue at times on native grounds. But the British had educated themselves in the ways of the "natives" just as the Indians had trained in the schools of the sahibs. Decades of learned commentary in the catalogues demonstrated that the agents of the Raj had developed a vast knowledge of Indian literature. In key cases, the cataloguers themselves testified in court. So the courtroom turned into a hermeneutic battlefield, where each side acted out its interpretation of the other and imperialism appeared, at least for a few moments while the muskets were stored in their racks, as a contest for symbolic dominance through textual exegesis.

Consider the following poem, which was published in a literary review, Pallichitra, in 1910 and typifies the material condemned as seditious in the courts. ${ }^{83}$ Because its author could not be identified (he was later found and sent to prison for two years), the editor of the volume, Bidhu Bhusan Bose, was put on trial before a district magistrate, R.C. Hamilton, in Khulna, Bengal. After pronouncing Bose guilty of sedition under Section 124A of the Indian penal code, the judge declared that he deserved to be transported for life, so heinous was his crime. In the end he was sentenced to two years of rigorous imprisonment, and his printer had to serve two months as an accomplice. What, then, was the wickedness in the following words, which are given in the translation from the Bengali provided by the official court translator? 


\section{Esho ma polli-rani}

Come Oh Mother Queen of the village, the day is drawing its full length to a close. Let thy children rise up with bounding hearts hearing thy great voice. I have sacrificed my life to take away the crown of victory from the enemy's brow and decorate thee thou Queen of Queens with it in the battle of life.

Led by mistaken ideas and tormented by passion, I did not perceive and could not feel at heart when (thy) golden seat disappeared.

Under the stamp of Asur's feet there are no Parijat flowers in the Nandan Gardens; and in the garb of a beggar, Indrani is sorely suffering in the most recess [sic] of her heart.

The Suras who have conquered death, see all this before them and like cowards shut up their eyes for hatred and shame. Oh, mother, I do not know when for the Swadesh, the gods will rise up in a body, and burning with rage as fierce as the worlddestroying fire kill the force of their adversaries, and relying on their own strength and taking up their own arms, re-establish the throne of the Heavens by offering drinks of blood to the manes.

To most of us, the poem is utterly opaque. To the district magistrate, it was clear: a case of rank sedition. There was nothing esoteric about it which an "ordinary reader" could not grasp, he claimed, for its meaning was transparent to anyone with an elementary knowledge of Hindu mythology: The queen was Mother India, also referred to as Indrani; the flowery garden was the paradise the British had destroyed; the Asur were devils, that is, the British; and the Suras were gods, that is, the Indians, now reduced to beggary but soon to rise and overthrow their oppressors. The context of current events made the message of the poem horrifyingly clear, as the magistrate explained it:

The poem was published...about the middle of July last; there had previously to its publication been a series of murderous attacks upon English men and women in India, upon British officials especially. The poem would be meaningless unless by the allusions to the slaughtering of the demons (asur) the British race were meant. The object of the writer evidently was to incite his Hindu fellow countrymen to join together to murder the British in India. In view of the terribly pernicious effect such literature as this is found to produce on the younger generation of Bengal,...not only is a deterrent sentence necessary, but it is also necessary to remove for some time to come, to prevent him further harming society, one who has been persistently harming society...I do not think there is any reason for treating his 
offence lightly. I accordingly sentence him to two years rigorous imprisonment.

This interpretation, however, had not gone uncontested. The judge reached it only after a hermeneutic free-for-all between the defense lawyer and the prosecuting attorney. According to the defense, words meant what dictionaries said they meant and what ordinary people understood them to mean. He quoted from dictionaries and called some man-in-the-street type witnesses in order to drive the point home. One key term, boyrishir in Bengali, could hardly refer to the British government, as the prosecution claimed, because its conventional meaning was "from the head of the enemy." Another, asur, meant the "forces of darkness." It could not refer to Englishmen, as he demonstrated by showing how it had been used in speeches of the viceroy. As to a third supposedly incriminating term, rudhir, it was used in common sayings such as "I will offer my blood", indicating a willingness to make a sacrifice. Anyone familiar with the customs of Hindus knew that they frequently sacrificed animals and that there was nothing offensive in the notion of blood being offered for a worthy cause. At the level of metaphor, the poem used the same figures of speech as in Hamlet's most famous soliloquy. It was a meditation on freedom, based on the opposition between town and country life, like Goldsmith's "Deserted Village." Indeed, Goldsmith's poem contained a much stronger declamation against tyranny, yet it was commonly read, with no ill effects, by Indian children in British schools. In case the British had forgotten how their own poets celebrated freedom, the defense lawyer treated the court to some stirring passages from Cowper. In comparison to Cowper, he insisted, his client was mildness itself. Of course, the author of the Bengali poem drew on Hindu mythology; but if the court were to forbid all such references, nothing would be left of vernacular literature. To read sedition into such a poem was to not merely to get it wrong, but to fan the flames of panic instead of calming them.

In rebuttal, the prosecutor raked over the text once more, arguing that the defense's reading of it compounded faulty definitions with incoherent metaphors. Asur, for example, could not mean "darkness", "for they are given legs and feet and described as trampling down paradise flowers under foot." The textual exegesis went on and on, until the judge called a halt and offered a reading of his own, line by line, and finally arrived at the bottom line: sedition. The trial had everything that one would expect to encounter in a modern class on poetry: philology, semantic fields, metaphorical patterns, ideological contexts, reader response, and interpretive communities.

Similar debates took place in case after case, for the authorities began to see sedition in all sorts of publications--histories, political pamphlets, religious tracts, plays, and song books. What had appeared as the harmless beginnings of a modern literature before 1905 stood condemned as revolutionary agitation by 1910 .

Literature now looked dangerous, because it was no longer restricted to the literati: it was spreading to the masses--that is, spreading disaffection, and disaffection meant sedition. Considering the impoverished and illiterate state of most Indian peasants, the diagnosis seems exaggerated. But the civil service took it seriously:

Inflammatory statements...are read with avidity and believed without question in bazaars and villages....From the original credulous readers, the report is disseminated among an illiterate population, whose susceptibility to the most extravagant rumors is proverbial, becoming 
in transit ever more distorted and more violent....The dak [post] arrives, bringing with it the Sandhya or Charu Mihir or other paper locally popular, and someone among the village leaders reads out passages to a collection of bhadralog and others under the shelter of a convenient tree. Even the passing cultivator lays down his plough and joins the expectant group. The poisonous extracts are heard and digested, and then all disperse and go their ways, retailing what they have learnt with heaven knows what embellishments and exaggerations. $^{84}$

Of course, newspapers, as indicated in this report from a district officer, seemed especially threatening, because they combined ideology with news. But books and pamphlets, especially collections of songs and texts of plays, could penetrate even more effectively into the world of the illiterate, because they were acted out in oral performances, which often combined music, mime, and drama. Consider two final examples of court cases.

On December 11, 1907, R. P. Horsbrugh, a district magistrate in Amraoti, Central Provinces, sentenced Swami Shivanad Guru Yoganand, alias Ganesh Yadeo Deshmukh, to transportation for seven years for distributing and declaiming a seditious songbook, Swarajya Sapan or Steps to Self-Government. ${ }^{85}$ Deshmukh wrote the songs, had them printed, and peddled them throughout the region, singing as he went. In order to promote sales--so the judge claimed--he changed his name and dressed as a mendicant holy man, a marketing strategy that appealed "...to the hearts of the illiterate many in every town and village through which he wandered." By "meter and music," the fake swami whipped up the emotions of "the credulous rustics who would be impressed only too readily by what fell from the lips of a sanyasi [Brahmin holy man]." The judge considered this "a very serious crime," sedition of a sort that used to be punished by death:

It is high time that the public generally realized that sedition in India is no longer a mere vituperative babbling which passes harmlessly over the heads of the mass of the people, as it did perhaps a quarter of a century ago. Education and internal communications have now been so largely developed, and a disaffected press has been so many years at work, that libels against the government...have become a political danger, which it is the duty of the criminal courts to check and, if possible, to uproot by stern justice.

As an example of Swami Shivanad's treachery, the judge cited the following verse from one of his songs:

O God having an elephant head and a crooked mouth. By turning your kind proboscis give in the hands of the Aryans the banner of devotion to the country.

It didn't sound like "God Save the King," but what did it mean? A bewildered Morley telegraphed to ask whether it merited seven years of transportation to Malaya. He was told that the elephant-headed god, Ganesh, was especially revered in the militant Hindu cult promoted by Tilak. Moreover, the prosecuting attorney had accumulated evidence of insubordination that struck closer to home: another song asserted, "It is a 
settled fact that Morley is a bitter Karela." (A karela is a balsam pear.) And still others played with powerful but confusing images:

O impotent! What for bow and arrow? By making their pockets empty let them feel a pinch in their stomachs. Show your mettle to the English by being resolute. By their oppressions or tyranny we do not get sufficient food, nor (do we get) water free. Abuses and curses are fruitless in the end. These selfish (Englishmen) eat the butter on the sinciput of one's dead brethren. Nobody pays heed to the complaints. (That they are) deceitful, of profound contrivance and thoroughly cunning is known to the entire world. Ward off or save yourselves (from these). By playing Pobara, let your counters go in a pair with the help of their own strength (so that) they (the English) will decamp. Government will be awe-struck. Language or words cannot describe the oppressions and calamities. No fodder has been left for cattle.

This text obviously challenged the exegetical capacities of the court. With help from the official translator, the judge supplied a critical gloss. The protests about poverty and exploitation included a reference to a recent increase in irrigation rates. The buttered sinciput referred to the Hindu custom of placing butter on the tops of the heads of corpses in order to facilitate cremation. And Pobara was a dice game, which evoked a kind of unity comparable to a perfect throw (a 6 on two dice and a 1 on the third), while at the same time punning in the original Marathi with notions of decamping and forming a league.

All this constituted some irreverent play with words, but sedition? Certainly not, said the swami's lawyer. The translation was all wrong. A native Marathi speaker would recognise the remark on eating butter as a reference to the writer's brethren, not to the English; and the punning about the dice game was nothing more than a verbal conceit. A later reference to Edward VII was perfectly respectful, as anyone could see by distinguishing which noun was the subject of the verb. The whole song expressed a mood of playfulness, not sedition; it merely needed to be read from the viewpoint of a native speaker. But the judge would have none of this argument. He rejected the defense's concept of translation in general and of the song in particular: "Not only would such a translation violate the rules of grammar, but it would disconnect the passage in syntax and in sense from everything which goes before and follows after it." In the end, of course, the prosecution won, and the swami went to jail.

The final case concerns Mukunda Lal Das, the leader of a "jatra party" or troupe of players, who toured by boat through the Ganges delta, performing dramas in peasant villages. Their greatest hit in 1908 was Matri Puja, a play adapted from a puranic tale about the conflict between the Daityas (demons) and the Devas (gods). After a successful run of performances in Calcutta, the play had been printed and registered in the catalogue for Bengal. But it was banned in 1908, when the keeper of the catalogue testified in court that it was a "seditious allegory" that attacked the leading figures in the Raj. ${ }^{86}$ When Mukunda performed it in the hinterland, he improvized lines to mock local officials and even the king-emperor, George V. He added mime, music, and song; and he also composed his own songbook, which went through several editions and circulated widely along with other songbooks, which took some of their material from his. From Sanskrit texts to modern books and from the Calcutta stage to village vaudeville, Matri Puja travelled across a vast stretch of 
culture. And when Mukunda took it to the masses, the ICS smelled sedition. District officers tried to stop his tour at many points, but he evaded them for nine months until finally, after 168 highly successful performances, he was arrested and brought to trial.

There were actually two trials, which took place before the same magistrate, V. Dawson, in Barisal in January and February 1909. The first concerned the songbook, the second the jatra tour. Both were linked with other cases and with a broad investigation of the nationalist movement by the ICS. At the heart of it all was "The White Rat Song", the biggest hit in Mukunda's extensive repertory, which the official translator rendered as follows: ${ }^{87}$

Babu, will you realise your situation when you die? The white devil is upon you (literally, upon your shoulders) and is totally ruining you. Formerly you used to take your food in gold dishes, but now you are satisfied with steel dishes. A second fool like you is not to be met with. You have liked pomatum neglecting the indigenous otto, and it is why they call you "brutes," "nonsense," and "foolish" (literally, do they willingly call you brutes, etc.) Your granary was full of paddy, but the white rat has destroyed it. Babu, just take off the specs, and look around you. Do you know, Deputy Babu, now your head is under the boots of the Feringhees, that they have ruined your caste and honor and carried away your riches cleverly?

The defense lawyer contended that the last line should read: "Status and rewards these days go only to businessmen, therefore go into business." Its meaning turned on the pronoun "they," which could not possibly refer to feringhees (foreigners), he argued, owing to the peculiarities of Bengali syntax and, in particular, the use of "the seventh case with the force of the nominative." Soon the court was embroiled in a debate about dictionaries, grammatical cases, Sanskrit roots, and the relative value of literal as opposed to figurative translations. But the judge finally put a stop to it with his verdict: Mukunda had committed sedition, and he would go to jail.

In rejecting esoteric exegesis, the judge conformed to a variety of legal hermeneutics set by the Tilak case of 1897, when Justice Strachey had instructed the jury (cases of sedition normally took place before juries until 1908, when magistrates were empowered to dispatch with them) to avoid too much sophistication: ${ }^{88}$

In judging of the intention of the accused, you must be guided not only by your estimate of the effect of the articles upon the minds of their readers, but also by your common sense, your knowledge of the world, your understanding of the meaning of words, and your experience of the way in which a man writes when he is animated by a particular feeling. Read the articles, and ask yourself, as men of the world, whether they impress you on the whole as a mere poem and a historical discussion without disloyal purpose, or as attacks on the British Government under the disguise of a poem and historical discussion. It may not be easy to express the difference in words; but the difference in tone and spirit and general drift between a writer who is trying to stir up ill-will and one who is not, is generally unmistakable. 
When it was intent on suppressing sedition, the Raj did not permit its courts to become entangled in Sanskrit syntax and Vedic mythology. Good, solid common sense would do--British common sense, though it was hardly common to the Indians. The judges therefore brushed aside "native" arguments about the meaning of words in a series of cases about seditious publications. In a typical case, which took place four months after the condemnation of Mukunda and also involved "The White Rat Song," the magistrate rejected an argument over etymology by a clever defense lawyer and delivered a hermeneutical pronouncement of his own: ${ }^{89}$

We must not go back to the etymological origin for the meaning of the words. To do this would in all probability pervert the meaning of all the songs. It is only one in a hundred who understands Sanskrit or who thinks of the Sanskrit equivalent when determining the meaning to be given to any particular word of the Bengali language.... The Bengali of the [White Rat] song is ridiculously simple and there can be no argument about the meaning which the man in the street would attach to it...I hold it amounts to an imputation that the English rulers have robbed the country of everything and have trodden even the Deputy Babus under foot. This is sedition pure and simple.

But Mukunda's case involved a great deal more than British intuition about Bengali linguistics. The ICS had worked on it for months, accumulating information that showed how the songs meshed with other cultural practices, which extended across a broad spectrum of Indian society. A background report on the case revealed that Mukunda and his players, a troupe or "party" of sixteen men, had been touring for at least two years through the complex river system of the Ganges delta. They travelled from village to village, followed by district officers with injunctions to forbid the performances. When an officer arrived, they piled into their boat and took their show to a new location across the district line. The ICS could map their progress across a large area of Eastern Bengal.

Thanks to local spies, the agents of the Raj also had a pretty good idea of what took place in Mukunda's jatras or musical dramas. "A favorite performance introduces an anti-swadeshi deputy magistrate and his wife," a district officer reported. In it, Mukunda "...referred opprobriously to Lord Curzon and Sir Bampfylde Fuller" (the Lieutenant Governor of Bengal.) The allusions were transparent in themselves, and they also were identified at the trial of the printer who had produced the published version of the Matri Puja--that is, the play which Mukunda had transformed into a jatra. The play's author, Kunja Behari Ganguli, had fled; so the court had to content itself by fining the printer 200 rupees and listening to a lecture on mythology and allegory by Manmatha Natha Rudra, the Bengal librarian and keeper of the catalogue. He testified that the play was "...clearly a seditious allegory on the present political situation of the country." 90 Ostensibly, the plot concerned nothing more than an ancient myth, but Rudra assured the court that it could easily be read as a commentary on current events:

The play is based on Chandi in the Markandeya Puran. The Daityas (giants inhabiting the nether world, but now generally used in the sense of demons) headed by their leaders, Sumbha and Nisumbha, have taken possession of the kingdom of heaven from the Devas (Gods) by force and are ruling it despotically. The Devas, three 
hundred and thirty millions in number, though usually divided among themselves and always envious of each other, are at last made by the oppression of their overlords to come to unity and by the help of the goddess Chandi (the mother of the world), who being insulted by the Daitya king, herself appears in battle, wins a victory over the Daityas and regains the kingdom of heaven.

The political incidents made use of in the play are:

1. The alleged attempt of the government to put down the cry of Bande Matram and what is called worship of the mother country.

2. The refusal of the people of Eastern Bengal to present addresses of welcome to Sir Bampfylde Fuller.

3. The desire of the nobility to please the Government, which is twitted.

4. The outbreak of famine.

5. The boycott of Manchester goods.

6 . The prosecution and whipping of students, which is represented as high-handed and unjustifiable persecution.

7. Persistence of students in the present agitation.

8. Visit of His Royal Highness The Prince of Wales to India and his wish expressed on his return to England that the people should be more sympathetically governed. The Daitya king in the play, who is represented as a good-hearted monarch with a sincere wish to rule his subjects well, regrets that he discarded the advice of his son under the arguments advanced by his counsellors, a set of Pisaches (devils) who are making the meek and weak shed tears, in order that they might extend their own mastery.

9. Outrage of women in Eastern Bengal.

The advocate-general of Bengal expanded on this interpretation by citing newspaper reviews, which linked the play to current politics. He showed how the names of the Deva leaders were acronyms of prominent nationalist politicians, while the supreme villain of the play, Crurjan, clearly referred to the viceroy, Lord Curzon. Nearly two years later, the British finally got their hands on Ganguli, the author of the play, who received a relatively lenient sentence of one year's imprisonment, because he pleaded guilty. He also said that he had received 400 rupees from Mukunda for the right to perform it. ${ }^{91}$

Mukunda's performances made the text come alive for the relatively unsophisticated audiences of the hinterland. The judge who condemned him acknowledged condescendingly that he had some facility with words: "The accused, though a person of inferior class, has higher literary attainments than are usually found in men of his class. He can at least sign his name in English and is the compiler of a book of songs." ${ }^{92}$ And district officers, despite their hostility, testified to his skill at striking a responsive chord among the "natives": "The amount of mischief which he has succeeded in doing may be guaged by the popularity of the performances, which is undoubted." In fact, Mukunda seems to have had considerable talent as a performer and director of jatra, which required an ability to improvize, act, sing, and mime. As he reworked it, Ganguli's text turned into a kind of vaudeville. Mukunda made the collaborationist Indian deputy magistrate--the "Deputy Babu" of "The White Rat Song"--into a stooge and threw in scornful 
references to the British--from the Viceroy down to local district officers--as the spirit moved him. While he improvized, the other actors followed his lead, breaking regularly into song. "On one occasion," a district officer reported, "his performance included the personation of His Majesty the King-Emperor, who was abused and insulted in an indecent manner by a member of the company representing the Indian people."

Although the troupe normally performed in peasant villages, it also played before some eminent Indians and adapted its standard fare to special occasions. In Manakhar the players put on a performance in a Brahmin's house before an image of the Goddess Kali. In another private home, they sang swadeshi songs before a group of prominent nationalists, including Aswini Kumar Dutt, who "...embraced him [Mukunda] with tears running down his cheeks, and the whole assembly shouted 'Bande Mataram."' Some performances seemed primarily to be concerts, others to serve as entertainment at nationalist rallies. Everywhere Mukunda whipped up audiences with "The White Rat Song"--"his best known and most objectionable," according to the agents of the ICS. He was hailed throughout the region as "the swadeshi jatrawalla."

When he came to the end of his tour in November 1908, Mukunda retired to his home Bakarganj, where at last the police arrested him. They searched the premises and the boat, turning up a great deal of incriminating evidence: the "libretto" of Matri Puja; songbooks; an account book, which showed that he had made a small fortune, 3,000 rupees, from the 168 performances; and correspondence with Aswini Kumar Dutt, which indicated that the jatras belonged to a vast campaign launched from Aswini's nationalist stronghold, the Braja Mohan Institution in Barisal.

The Braja Mohan Institution was both a school and a kind of samiti, or home base for nationalist agitation. To the ICS, which followed its activities intensely, it was "a revolutionary organization, designed and trained for an eventual rising against the British government." ${ }^{93}$ It had 159 branches in Eastern Bengal, and Aswini Kumar Dutt, its proprietor, had connections with the most famous nationalist leaders, notably Tilak. While providing boys with a basic education, it instructed them in "lathi play" (a military drill, involving a traditional club with a metal head) and trained them to spread the message of swadeshi. They accompanied convicted publicists to jail and escorted them home on their release, chanting Bande Mataram. They promoted the boycott of British goods by burning imported cloth. At religious festivals (melas), they proselytized pilgrims. During demonstrations, they tied rakhis (red threads) on people's arms to symbolize the blood to be shed in the struggle for independence. They persuaded Brahmins to refuse religious rites to local dignitaries who collaborated with the British. And they also tried to force compliance with swadeshi by getting barbers, laundresses, servants, and even prostitutes to refuse their services to those who wavered. Through it all, they sang nationalist songs, especially those by Mukunda. ${ }^{94}$

The reports on these activities by nervous district officers should not be taken literally. They do not prove that India was about to explode in revolution, but they suggest the context of Mukunda's performances and the ways in which his songs resonated in the surrounding culture. The songs themselves came straight out of the Braja Mohan Institution, which provided Mukunda with a base. One of the teachers at the school, Bhabaranjan Mazumdar, included "The White Rat Song" with several others in a songbook, Deser Gan, which he had printed in Barisal. It went through three editions, the last at a pressrun of 1,000 copies; and he had it peddled by the schoolboys, along with nationalist pamphlets, which he also had printed. The police 
tracked the publications to their source, and Mazumdar was sentenced to eighteen months in prison after a trial that included the usual debates about language and puranic mythology. ${ }^{95}$ Mukunda produced his own songbook, Matri Puja Gan, at the same time and with the same printer. It consisted of 53 songs, many of them, "The White Rat" included, from the libretto that he had composed for the jatra version of Ganguli's play. The prosecuting attorney made the songbook the centerpiece of the first of the two sedition trials involving Mukunda. He had all 53 songs translated and concentrated on four of them, in order to prove, by explication de texte, that Mukunda had fomented sedition through the publication of a revolutionary tract. After considerable discussion of Daityas and Devas, the judge pronounced the inevitable verdict: guilty under section 124A. He sentenced Mukunda to a year in prison, and then added two more years in the subsequent trial, which concerned the jatra tour.

Mukunda received twice as long a prison term for his singing as for the publication of his songs--testimony to the importance of oral communication in a society with a low rate of literacy. But the communication process involved a great deal more than adapting printed texts to diffusion by word of mouth. To Mukunda's audience, culture was performed. For his message to take, it had to be acted out and embellished with commentary in gesture and in song. Therefore jatras, as he perfected them, carried the message of swadeshi far beyond the range of the printed word. Their effectiveness was acknowledged by the judge, when he declared Mukunda guilty: "There can be no question that the harm done by the accused by penetrations into remote villages with his mischievous propaganda was infinitely greater than the harm done by him in publishing a printed book." To be sure, jatras were a specialty of Bengal, but popular theater posed the same threat to the Raj everywhere. At the other extreme of the subcontinent, the secretary to the Government of Bombay warned the Government of India:

There has been a great increase in the number of plays of a seditious character, which are performed before large audiences at all the larger centers of population.... The effect of such plays is even more pernicious than that of the seditious press, for they appeal to persons who are not reached by the newspapers, and the passions are more easily excited by what is represented in action on the stage than by what is merely read." 96

The printed word was powerful, nonetheless, because it became transmuted into other forms. Hence the history of "The White Rat Song": it spread through the population by means of performances as well as songbooks, and it conveyed a message that combined Sanskrit literature and contemporary politics. Faced with a culture of such complexity, the ICS felt threatened and the courts confused. But the British had a monopoly of power. When they exerted it, they got their man and condemned him in their court.

What ultimately was going on in the courtrooms of the Raj? Censorship, certainly, because the British used the trials as a means to deter and repress. But they could have clapped the authors and publishers in prison without running them through elaborate legal rituals. Instead, they tried to prove their cases--that is, to demonstrate the justice of their rule to the "natives" and, even more important, to themselves. If the Raj could not be identified with the rule of law, it might be seen to rule by force. If its judges did not uphold the freedom of the press, they might be taken as the agents of tyranny. Yet they could not allow the Indians to use words as freely as Englishmen 
did at home. So they construed "feelings of enmity" as "disaffection" and "disaffection" as "sedition", translating freely from one idiom to another as the need arose. That the Indians sometimes outplayed them at their own game made no difference, for the British had the ultimate answer: force. Not that they impounded and imprisoned on a great scale. For the most part, they remained true to form, clinging to common sense and muddling through contradictions. Liberal imperialism was the greatest contradiction of them all; so the agents of the Raj summoned up as much ceremony as they could, in order to prevent themselves from seeing it. 
Notes

1 "An Act for the regulation of printing presses and newspapers, for the preservation of copies of books printed in British India, and for the registration of such books," Act No. XXV of 1867 in $\underline{A}$ Collection of the Acts Passed by the Governor General of India in Council in the Year 1867 (Calcutta, 1868), Oriental and India Office Collections, The British Library, V/8/40. The Act explained that the catalogue would be considered as a "Book of Registry" and that the publications registered in it would be deemed to be copyrighted according to Act XX of 1847, which first laid down the rules for copyright in British India. All books and pamphlets had to be submitted for registration within a month of publication, and the publishers were paid for the three deposit copies until 1890, when the provision for payment was dropped. There was no requirement for permission to publish and no reference to censorship of any kind, either before or after publication. Every book had to include the name and address of the printer, and no one could keep a printing press without making a declaration to the local magistrate, who was ultimately responsible for the execution of the law. In principle, therefore, the publishing of books was free of censorship and subject only to laws of sedition and libel, as in England. The Act laid down detailed instructions for the production of "memoranda" or the forms that were printed in the catalogues, and the actual catalogues conform exactly to those requirements, except that a sixteenth rubric, "Remarks", was added in 1871. That rubric grew until it contained so much material that it was finally dropped in 1901. I have not found an account of how Lawler filled in the forms, which he endorsed by signing his name. He probably was helped by a small staff. All subsequent references are to the archives of the Oriental and India Office Collections, the British Library, unless indicated otherwise. I would like to thank Graham W. Shaw, Deputy Director of the Oriental and India Office Collections, for his help and hospitality during two summers of research.

${ }^{2}$ Although there are several ways of estimating book production in eighteenth-century France, none of them is adequate. Robert Estivals, who has studied the sources in great detail, notes that one indicator, requests for official permission to publish books (privileges and permissions tacites), shows a total of 31,816 titles submitted for the period 1724-1787, an average of 530 a year. According to another index, deposit copies left in the royal library, 28,585 new works were produced between 1684 and 1789, an average of 270 a year. See Robert Estivals, La statistique bibliographique de la France sous la monarchie au XVIIIe siècle (Paris, 1965), especially pp. 304 and 343. These figures cannot be compared effectively with those given below on book production in India, because a large proportion of French works were illegal and were produced surreptitiously in France or in nearby countries.

3 Bengal Library Catalogue of Books, printed as an appendix to the Calcutta Gazette, second quarter, 1879, Z Y CH.

4 All quotations come from the Bengal Library Catalogue of Books for 1879, where they can be found under the titles of the books.

5 G. W. Shaw, South Asia and Burma Retrospective Bibliography. Stage 1: 1556-1800 (London, 1987) describes 1771 titles printed in 8 European and 19 oriental languages. The following account is also indebted to the unpublished paper kindly made available to me by G. W. Shaw, "The History of Printing in South Asia: A Survey of Research Since 1970."

6 A.K. Priolkar, "Indian Incunabula," in D.N. Marshall and N.N. Gidwani, Comparative Librarianship: Essays in Honour of Professor D.N. Marshall (New Delhi, 1973), pp. 129-135.

$7 \quad$ C.A. Bayly, "Knowing the Country: Empire and Information in India," Modern Asian Studies XXVII (1993), 3-43; C. A. Bayly, An Empire of Information: Political Intelligence and Social Communication in North India, c. 1780-1880 (New York, 1997); and Bernard S. Cohn, "The Census, Social Structure and Objectification in South Asia" in Cohn, An Anthropologist among the Historians and Other Essays (Delhi and Oxford, 1987). For a vivid account of the frustrations of a district officer with an amazing knowledge of Indian languages, see John Beames, Memoirs of a Bengal Civilian (London, 1984). Kipling's Kim is a less reliable source, but its descriptions of espionage and information gathering should not be dismissed as mere poetic fantasy. 
8 For a fuller account of these complex topics, see standard histories, such as Stanley Wolpert, $\underline{A}$ New History of India (New York, 1993) and Percival Spear, The Oxford History of Modern India $\underline{1740-1975}$ (Delhi, 1989); and for more information on specific subjects, see monographs such as David Kopf, British Orientalism and the Bengal Renaissance (Berkeley, 1969); Sudhir Chandra, The Oppressive Present. Literature and Social Consciousness in Colonial India (Delhi, 1994); and Homi Bhabha, The Location of Culture (London, 1994).

9 The quotations, cited in the order of their appearance in the text, come from the Bengal Library Catalogue of Books for 1871 prepared by John Robinson, librarian at that time. They concern the following works, whose titles are given as transliterated and translated in the catalogue: Brujeshwuree Kabuy, or Poem entitled Brujeshwuree ; Rujuneekantu, or The Moon; Kabyukoosoom, or The Flower of Poesy.

10 The Bengal catalogues, the most voluminous by far of those in all the presidencies, were published every quarter and signed by the librarians in their capacity of "Librarian of the Bengal Library and Keeper of the Catalogue of Books:" John Robinson from 1867 to October 1878 (except for brief periods when he was replaced by R. J. Ellis and Robert Robinson), William Lawler from October 1878 to June 1879, Chunder Nath Bose from June 1879 to October 1887, Haraprasad Shastri from October 1887 to January 1895, and Rajendra Chandra Sastri from January 1895 to March 1907. The column of remarks was eliminated in 1901, and the format was simplified somewhat in 1902 and in 1905, when titles appeared in native characters instead of in transliteration.

11 Bengal Library Catalogue of Books, 1880. Owing to the lack of continuous pagination in the catalogues, quotations must be found following the title of the work in the volume for the appropriate year, in this case: Surendra-Binodini Nátak.

12 The son of a government official in Raipur, Central Provinces, Harinath De had been educated at Raipur High School, Presidency College, Calcutta, and Christ's College, Cambridge, where he got a first class in the classical tripos, and a second in the tripos in medieval and modern languages. As librarian of the Imperial Library in Calcutta, his responsibilities extended over the entire Raj and therefore, unlike the librarian of the Bengal Library, he did not prepare the catalogue of a particular presidency. See Oriental and India Office Collections, The British Library, P/7587, Pro. Nos. 201 and 237-243.

\section{Bengal Library Catalogue of Books, 1874.}

14 Ibid., 1879: Hita-shiksha or Useful Instruction.

15 Ibid., 1878. It may be, of course, that the book really was incoherent. The Indian librarians could be just as uninhibited as their British predecessors in expressing scorn for incomprehensible writing. Thus the remarks by Rajendra Chandra Sastri in the catalogue for 1900 on Astray Siddhanta Chandrodaya Va Svarup Damodar Gosvamir Karcha: "A metrical discourse on some of the most abstruse and esoteric doctrines of Vaishnavism. The work is full of unintelligible technicalities and mysticisms."

16 Sympathetic remarks about native medicine can be traced back to the catalogue of 1878, where John Robinson had nothing but praise for Deshiya prakriti o chikitsa or The Constitution and Medical System of the Country: "The European system of medicine and treatment not adapted to the constitution of natives of the country. Reference is made to their being so tender about the spleen." On polygamy see the remarks on Buhoobibahu Rahityarahityu Neernuyu or $\underline{A}$ Determination of Whether Polygamy Ought To Be Abolished or Not in the catalogue of 1871. On religion, see the favorable review of Krishna Bhakti Sar or The Truths of the Devotion to Krishna as contrasted with the condemnation of "idolatrous" Hindu devotion in Assamya Larar Ditya Shikhya or The Second Lesson Book for Assamese Children in the catalogue for 1874.

17 Remarks on Moonlight of the Worship of the Goddess Kali, ibid., 1879. 
18 Ibid., 1878. For remarks on the Ramayana and the Vedanta, see the reviews of Nirbasita Seeta or The Banished Seeta in the catalogue for 1871 and Sriyukta Babu Srigopal Basu Malliker Phelosiper Lekchar or Srigopal Basu Mallick's Fellowship Lectures and Nigurha Atma-darsan or Esoteric Self-Perception, both in the catalogue for 1900.

19 As an example, see Bhubudeb Puddhuti or The Institutes of Bhubudeb in the catalogue for 1871. There is a vast amount of information on chapbook literature in the catalogues. Unlike its European counterparts, it has not, as far as I know, been studied.

20 James Long, Returns Relating to the Publications in the Bengali Language in 1857, to which is Added a List of the Native Presses, with the Books Printed at Each, their Price and Character, with a Notice of the Past Condition and Future Prospects of the Venacular Press of Bengal, and the Statistics of the Bombay and Madras Vernacular Presses (Calcutta, 1859), The British Library, Oriental and India Office Collections, V/23/97, p. xv. This remarkable work provides a detailed description of all the varieties of popular literature mentioned above. It also describes practices of reading, p. xv: "With Orientals it is a common practice to be read to, and hence numbers who cannot read themselves listen to those who can. Readers (kathaks) are often hired to recite or chant certain works, and most impressively do some of them execute this--one of them recited lately to myself from memory any passages I selected from the Ramayan, Raghuvansa, Mahabharat; the mode of reciting them was most impressive; some of these men earn 500 rupees a month....We know a native who was for years employed by a rich babu to read two hours daily to 40 or 50 females in his house. This has been a practice from time immemorial in Bengal, where "readings" as in all Eastern countries have been so popular, and where intonation, gesture, etc. make a book listened to more telling than when simply read. Women sometimes sit in a circle round a woman, who reads a book to them. Allowing them an average of 10 hearers or readers to each book, we calculate that these 600,000 Bengali books [the total number of copies produced, according to Long's estimate] have 2,000,000 readers or hearers." Lawler himself also described popular readings: "Report on the Bengal Library for the Year 1878," V/23/24: "Frequently in this very town of Calcutta an observant passer-by sees a large knot of natives collected round a tailor or native grocer's shop to hear a man...reading a tale in MusulmaniBengali, in which the auditors appear to take the most lively interest....[The reading] is always rapid, sonorous, and musical, and must be accompanied with rapid motions of the head and body, without which he could not go on."

21 Bengal Library Catalogue of Books, 1875.

22 Ibid., 1875.

23 Rama-vanavas-natak, or The Residence of Rma in the Forest, Ibid., 1879.

24 For example, the following remarks from the catalogue for 1900: "Thakur-Jhi, or Father-inLaw's Daughter...is a story of everyday life relating how a young man of good education and character named Hiralal was well nigh ruined by his drinking habit, and how his rescue and reformation were due to the self-sacrificing efforts of his sister....A sincere devotion to her brother is the principal trait in her character, and it is this devotion which sustained Hiralal in his days of trial and adversity and ultimately reawakened his dormant moral nature."

25 Several of these crime thrillers published by the manufacturers of Kuntalin and Mohiya hair oil appear in the catalogue for 1908.

26 Ranga Bau Va Sikshita Malila or Beautiful Daughter-in-Law or the Education of a Lady in Ibid., 1900.

27 See, for example, Galpa-guchchha, or A Cluster of Stories, Ibid., 1900.

28 Swarnalata (a proper name), Ibid., 1881. 
29 Paramartha Prasanga or Discourses on the Highest Truth Ibid., 1900.

30 The catalogue included a separate section for periodicals. In 1873 it welcomed the appearance of a new literary review, Bangadarshan or The Mirror of Bengal as follows: "A very superior literary magazine and review, both the editors and contributors being among the ablest of Bengali writers."

31 Vina or Lyre in Ibid, 1900.

32 The remarks on Vidyasagar's Sankhya Darsan or Sankhya Philosophy in the catalogue for 1900 indicate reservations about the attempt to mix Western ideas with traditional Indian philosophy: "It is an extremely interesting and original exposition of the principles of Sankhya Philosophy, based mainly on the aphorisms of Kapila and differing fundamentally from the views of standard authors on the subject. This attempt to look beyond the traditional interpretation and to substitute in place of it views and ideas which are possibly suggested by the writings of European authors must always be looked upon with suspicion....There is no denying that the book contains evidence of clear thinking, close reasoning and an honest and fearless devotion to truth, which is rarely met with in an equal degree in the writings of any other Bengali author of the present day. The writer's untimely death has been a great loss to Bengali literature."

33 Ibid., 1900.

34 Ibid., 1900.

35 Ibid., 1900. See also the comments in this catalogue on Sachitra Gris Turaska-Yuddha, or Graeco-Turkish War with Illustrations and Tetavatar Ramachandra or Ramachandra, the Incarnation of the Treta Era. Similar remarks can be found in the earlier catalogues, notably the one for 1878.

36 On the broadly political aspect of the vernacular literatures in nineteenth-century India, see Sudhir Chandra, The Oppressive Present. Literature and Social Consciousness in Colonial India (Delhi, 1994).

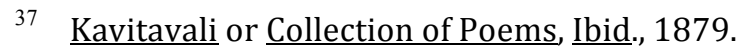

38 See, for example, the remarks on Jel Darpan Natak, or Mirror Depicting the Jail in Ibid., 1876: "The work commences with a dialogue between two of the principal actors in the case of the Guikwar of Baroda, in which unfavorable comments as to the action taken therein by Government. A little further on, and forming the main part of the book, the immunities permitted in the civil jail are contrasted with the heart-rending treatment by the jail authorities of prisoners in the criminal jail. The native doctor is depicted as kind and sympathetic, whilst the civil surgeons and the magistrates are, on the other hand, represented as heartlessly cruel, especially in flogging the prisoners. The drama comprises scenes in the Alipore, Jessore, Burdwan, Narail and Bankoora jails. The Jessore jail stands out most prominently in the cruel treatment of its prisoners, one of whom is represented as having died from the effects of the lashes administered to him whilst in prison." Other examples include Baranabater Lukochuri, or Hide and Seek at Baranabat, Ibid., 1874; Surendra Binodini Natak (proper names), Ibid., 1875; and Sharat Sarojini, Natak (proper names), Ibid., 1876.

39 Cha-kar Darpan Natak,or The Mirror of a Tea Planter, Ibid., 1875: "This drama sets forth the dreadful oppressions and cruelties of the tea planters and their amlahs, and taunts the British government with efforts to do away with slavery in other lands, whilst in their own possessions such heart-rending scenes are practised."

40 Sabhyata Sopan, Drishya Samajchitra, or Stepping Stone to Enlightenment, Ibid., 1878.

41 Some typical examples from the catalogue of 1876: Dasatwa-shrinkhala, or The Bonds of Slavery: "Describes the bondage of the people of India, whose acts and wills are made 
subservient to the orders of others." Manihara-phani Barat janani, or Our Mother India is like the Serpent who Has Lost its Wonderful Jewel: "Describes the growing ills of India since it passed into the hands of foreigners." Gyandipika or The Light of Knowledge: "Discourse on the law and administration of the country, pointing out existing defects."

42 Ingraj Goonu Burnun, or A Description of the Virtues of the English, Ibid., 1871. See also Satik Pauchali, or Metrical Verses, Ibid., 1876, which praised the British "...for the introduction of the telegraph, the steam boat, the railway, the administration of justice, etc."

43 Rajputra, or The Prince, Ibid., 1876. On the anti-Mughal view of Indian history, see Bharathe Jaban, or The Mohammedans in India, Ibid, 1874: "The tyrannical acts of the Mohammedans during their rule in India--killing cows and Brahmins and violating the chastity of women, till the English came to the rescue of India."

44 Inraj Pratibha, or Genius of the English, Ibid., 1910.

45 Bharat Kahini, or The Story of India Ibid., 1900: “...They [the Indians] must be true to the cardinal principles of their religion and set their faces against imitating the mere forms, without spirit, of western civilization and avoid ultra radicalism in the matter of social and religious reform. The Congress movement is no doubt a good thing, but mere political agitation can not save the country. Let the people work more and talk less, and they will rise in the estimation of government. The book is written in an excellent spirit and freely acknowledges the benefit of British rule."

46 See, for example, Daiva-lata, or Creeper of Providence, Ibid., 1879: "The writer...praises the English for their just administration and hopes that they will long continue to rule the country and that all India should be grateful for the benefits received from English rule." Not surprisingly, this theme also appeared in works written in English, such as High Education in India, Ibid., 1878.

${ }^{47}$ Ibid., 1879.

${ }^{48}$ Thus Sarat-Sashi (a proper name) as described in the catalogue for 1881: "The hero is a young Bengali Babu, who knows English, has shaken off the bonds of caste and superstition, is full of patriotic fire, is a practical philanthropist, exposes official corruption and wickedness, writes articles in newspapers, hates tyranny and oppression of all kinds, is in short the author's ideal of what educated Bengalis should be."

${ }^{49}$ Is This Called Civilization?, a Bengali drama translated into English: Ibid., 1871.

${ }^{50}$ In reviewing Kajer Khatam, or The End of the Business, "a farce written in defense of native theatres," the librarian noted in the catalogue of 1900, "The affectation of Anglicism by 'Englandreturned' gentlemen forms, as usual, one of the staple topics of ridicule."

${ }^{51}$ For example, Bharat-uddhara, athaba chari-ana matra, or The Deliverance of India, or Four Annas Only, Ibid., 1878: "The writer ridicules the military aspirations of the so-called educated Bengalis, who, though entirely devoid of courage and strength, are impatient of the abject condition of their country, and always in their speeches express their desire to rid it of foreign domination....The writer refers throughout to the habits of drinking, the timidity, inaptitude for action, and love of speechifying, and the utter shallowness which characterize Bengalis."

${ }_{53}^{52}$ Bharat-Ishwari, or The Empress of India, Ibid., 1877.

${ }^{53}$ For example, Sukhamukur Kavya, or The Mirror of Happiness, Ibid., 1878: “The present weak and degraded condition of the descendants of the Aryan race, their subjection to a foreign power, and their habits of intemperance are all described in language of some force." See also in the catalogue of 1878: Manas Kusum, or The Flowers of Fancy and Bharate dukh, or India in Distress.

${ }_{54}$ Aryua Jati, or The Aryan Race, Ibid., 1900: "The influence of Western education on Hindu Society of the present day is pronounced to be distinctly harmful, and the establishment of a Hindu religious association is advocated as a means of combating that influence and fostering a spirit of nationality and brotherhood among the different sections of the Hindus."

${ }^{55}$ Kavi-kahini, or Narrations by a Poet, Ibid., 1876. See also Swadeshanurag-uddipak Sangita, or Songs Stimulating Patriotism, Ibid., 1878.

${ }^{56}$ The reports, rich and elaborate documents that cover all ten provinces, were issued by the Home Department of the Government of India under the title "Reports on Publications Issued and Registered 
in the Several Provinces of British India." I have made a detailed study of those from 1874 (V/23/28), $1879(\mathrm{~V} / 23 / 34)$, and $1898(\mathrm{~V} / 23 / 76)$.

57 "Report on Publications Issued and Registered in the Several Provinces of British India During the Year $1898, " \mathrm{~V} / 23 / 76$. The report runs to 133 pages and contains statistics for each of the 10 provinces broken down according to the principal languages used in them. I have amalgamated all the statistics into one table for each province. That procedure makes it possible to have a general view of book production by genre and region, but it does not do justice to the enormous linguistic variety in the year's crop of books. In the presidency of Madras, for example, books appeared in 41 languages or combinations of languages, including Tamil, Telugu, Malayalam, Kanarese, Tulu, Konkani, Uriya, Hindustani, Sanskrit, Persian, Arabic, English, Latin, and German.

${ }^{58}$ Ibid., section on Bengal. Until 1890, publishers received payment for the copies that they deposited for registration in the catalogues. After 1890, the keepers of the catalogues noted an increased tendency to avoid registration, even though it was a legal requirement. Nevertheless, overall book production, as measured by the catalogues, rose constantly throughout the nineteenth century. The exception was 1898, when the cataloguers estimated that production had decreased by almost 5 per cent as a consequence of the plague of 1897. I have compiled statistics from the "Report on Publications" of 1878 for the presidencies of Madras, Bombay, Bengal and the North-Western Provinces with Oudh. They show a total output of 3,847 titles as compared with 5,3221 titles for 1898. Taken together, those four regions account for the dominant proportion of book production in all of India. There are no statistics for the entire subcontinent, but I would consider 200,000 titles to be a modest estimate of the total output for the nineteenth century.

59 "Publications Registered at Curator's Office, Allahabad During the Year 1869," in "Selections from the Records of Government, North-Western Provinces" (1870), V/23/129.

${ }^{60}$ The authorities seem to have been fairly vigilant about the import of seditious literature during the nationalist agitation of the early twentieth century, as indicated in the "confidential" political papers of the Home Department Proceedings of the Government of India: P/7587, P/7590, P/7875, P/8153, $\mathrm{P} / 8430, \mathrm{P} / 8431$. But a careful reading of those papers turned up relatively few cases involving sedition as the British understood it. In November, 1906, for example, the police confiscated three boxes of books and periodicals that had been shipped from Cairo to M. A. Jetekar, a bookseller in Bendi Bazaar, Bombay. Most of the books were Arabic treatises on religion and law, but one of the journal articles called upon the Egyptians to overthrow their British conquerors. Jetekar was judged to be a "respectable" dealer during his interrogation and was released after promising to cancel his subscription to the periodical: $\mathrm{P} / 7587$, pro. no. 258. In 1908, Bombay officials received special authority to intercept the mail in order to confiscate copies of a book on the Mutiny of 1857 by V. D. Savarkar: P/8153, pro. nos. 23-27. In 1909 the French authorities in Pondicherry offered to cooperate with the British but tolerated the printing of journals like India, which had moved to their territory from Madras. Judging from the confidential correspondence in the India Office, the French enjoyed lecturing the British on "...the limits permitted by the French legislature on the subject of the liberty of the press": Minto to Morley, April 1, 1809, P/8153, pro. nos. 44-52. But the correspondence does not suggest that Pondicherry functioned as a source of forbidden books in a manner comparable to Amsterdam and Geneva in eighteenth-century Europe.

${ }^{61}$ Insofar as any studies exist of the vernacular press and the attempts to control it, they concern newspapers. I know of no general work on the history of the book in India or on the policing of publishing and the book trade. Gerald Barrier, Banned. Controversial Literature and Political Control in British India, 1907-1974 (Columbia, Missouri, 1974) is useful but contains little information about the period 1857-1911. The India Civil Service produced its own compilation of legislation concerning the press in India: G. K. Roy, Law Relating to Press and Sedition (Simla, 1915): V 5597. But I have found it necessary to go back to the original texts in the Oriental and India Office Collections of the British Library.

${ }^{62}$ See the rich documents collected in "Tracts. Indigo. 143" and W 977 and Ranajit Guha, "NeelDarpan: The Image of a Peasant Revolt in a Liberal Mirror," The Journal of Peasant Studies, II (1974), $1-46$.

${ }^{63}$ This account is based primarily on the documents in the Oriental and India Office Collections of the British Library, but it also draws on Sumit Sarkar, The Swadeshi Movement in Bengal 1903-1908 (New Delhi, 1973) and Peter van der Veer, Religious Nationalism: Hindus and Muslims in India (Berkeley, 1994) as well as on standard histories of India.

${ }^{64}$ Dispatch of Denzil Ibbetson, April 30, 1907, P/7590, pro. no. 183: "The Punjabi is no doubt less hysterical than the Bengali. But he is not exempt from the defects of the East. Credulous to a degree which is difficult for us to understand, traditionally disposed to believe evil of his government, difficult 
to arouse, perhaps, but emotional and inflammable when once aroused, he affords ground admirably adapted to the purposes of the political agitator." The documents in this and the following series in the archives of the Oriental and India Office Collections are gathered in bound volumes that do not have pagination; so references are to their "progress numbers" or pro. nos.

${ }_{65}$ Dispatch of Sir Herbert White, August 1, 1907, P/7590, pro. no. 69.

${ }^{66}$ Dispatch of H. J. Stanyon, July 28, 1907, P/7590, pro. no. 71.

${ }^{67}$ Dispatch of the Commissioner of the Nagpur Division, August 7, 1907, P/7590, pro. no. 71.

${ }^{68}$ See the dispatches from the North Western Frontier Province, July 29, 1907, P/7590, pro. no. 72; from Eastern Bengal and Assam, March 24, 1908, P/7875, pro. no. 24; and from Mysore, Sept. 1, 1909 , $\mathrm{P} / 8430$, pro. no. 65 .

${ }^{69}$ Minto to Morley, July 11, 1907, P/7590, pro. no. 31: "Nothing can be further from our intentions or more opposed to the spirit of our general policy than to interfere in any way with the legitimate functions of the press. But when the public safety is in danger, we claim for the executive government the right to intervene....Here is no question of the liberty of the press. The object is simply to stir up disaffection."

${ }^{70}$ Cotton penetrated the weak points in Morley's policy so effectively that Morley came to dread his questions and requested information from India that would provide some protection: Morley to Minto, July 5, 1907, P/7590, pro. no. 31; Morley to Minto, April 25, 1910, P/8430, pro. no. 55. See also the related information in the dispatches of July 29, October 22, and December 17, 1908: P/8153, pro. nos. 15, 21, and 36; and the published version of the Minto-Morley correspondence: India, Minto and Morley, 1905-1910; Compiled from the Correspondence between the Viceroy and the Secretary of State by Mary, Countess of Minto (London, 1935).

${ }^{71}$ See the reports on the raid in Calcutta of May 2, 1908 in P/7875, pp. 625 and 971.

${ }^{72}$ Dispatch from the government of Bombay, July 30, 1909, P/8430, pro. no. 65.

${ }_{74}^{73}$ Dispatch from the Viceroy's office, June 17, 1910, P/8431, pro. no. 159.

${ }^{74} \mathrm{P} / 7875$, pro. no. 95 . The government also refused to allow the import of a translation of an essay by Tolstoy, Ek Hindu pratye Mahan Tolstoy no Kagal or Great Tolstoy's Letter to a Hindu, which the young M. K. Ghandi produced as a pamphlet in South Africa. In describing Ghandi, a translator for the government of Bengal warned, "Though he pretends to be a lover of peace and a thorough passive resister, he evidently wants to drive the English out of India, and freely gives utterance to sentiments which are not calculated to teach peace and good will towards the ruling nation": P/18431, pro. no. 69 . The police later confiscated a copy of Ghandi's Gujurati pamphlet Hind Swaraj or Indian Home Rule, He reacted by sending an English translation to the Government of India, "...entirely to assist it. This in no way means that I necessarily approve of any or all the actions of the Government, or the methods on which it is based. In my humble opinion, every man has a right to hold any opinion he chooses, and to give effect to it also, so long as, in doing so, he does not use physical violence": Ghandi to the Government of India, April 16, 1910, P/8431, pro. no. 96.

${ }^{75}$ Dispatch of M. W. Fenton in the Punjab, June 11, 1909, P/8153, pro. no. 145.

${ }^{76}$ Reports on seditious literature in the Punjab, May-July, 1909, P/ 8153, pro. nos. 145-153.

${ }_{77}^{77}$ See the cases in $\mathrm{P} / 8431$, pro. nos. $117-134$ and $\mathrm{P} / 8153$, pro. nos. 89-94.

${ }^{78}$ The key text in Section 124A, chapter VI, p. 424 of the Indian Penal Code of 1860, reads as follows: "Whoever by words, either spoken or intended to be read, or by signs, or by visible representation or otherwise, excites or attempts to excite feelings of disaffection to the Government established by law in British India, shall be punished with transportation for life or for any term, to which fine may be added...": V/8/319. An "Explanation," which followed, attempted, not very successfully, to make clear that disaffection "...is not the expression of disapprobation of Government measures by one disposed to be obedient to its authority." In a separate section, pp. 292-293, which had nothing to do with sedition, the Code forbade the sale of obscene books and prints.

${ }^{79}$ The documentation concerning both Tilak cases was reproduced in Law Relating to Press and

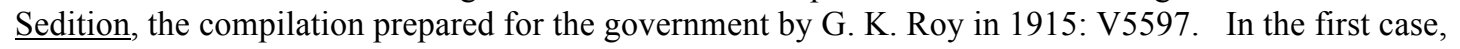
the judge construed "disaffection" in a broad way, despite the defense argument that the term was impossibly vague.

80 "Indian Penal Code Amendment Act, 1898," ibid., p. 11. This law also added a new section, 153A, which provided severe punishment for anyone "...who promotes or attempts to promote feelings of enmity or hatred between different classes of Her Majesty's subjects." Although intended primarily to prevent hostility between Hindus and Muslims, section 153A was later used to punish insulting remarks by Indians against Britons.

81 "Indian Press Act of 1910," ibid., p. 45. 


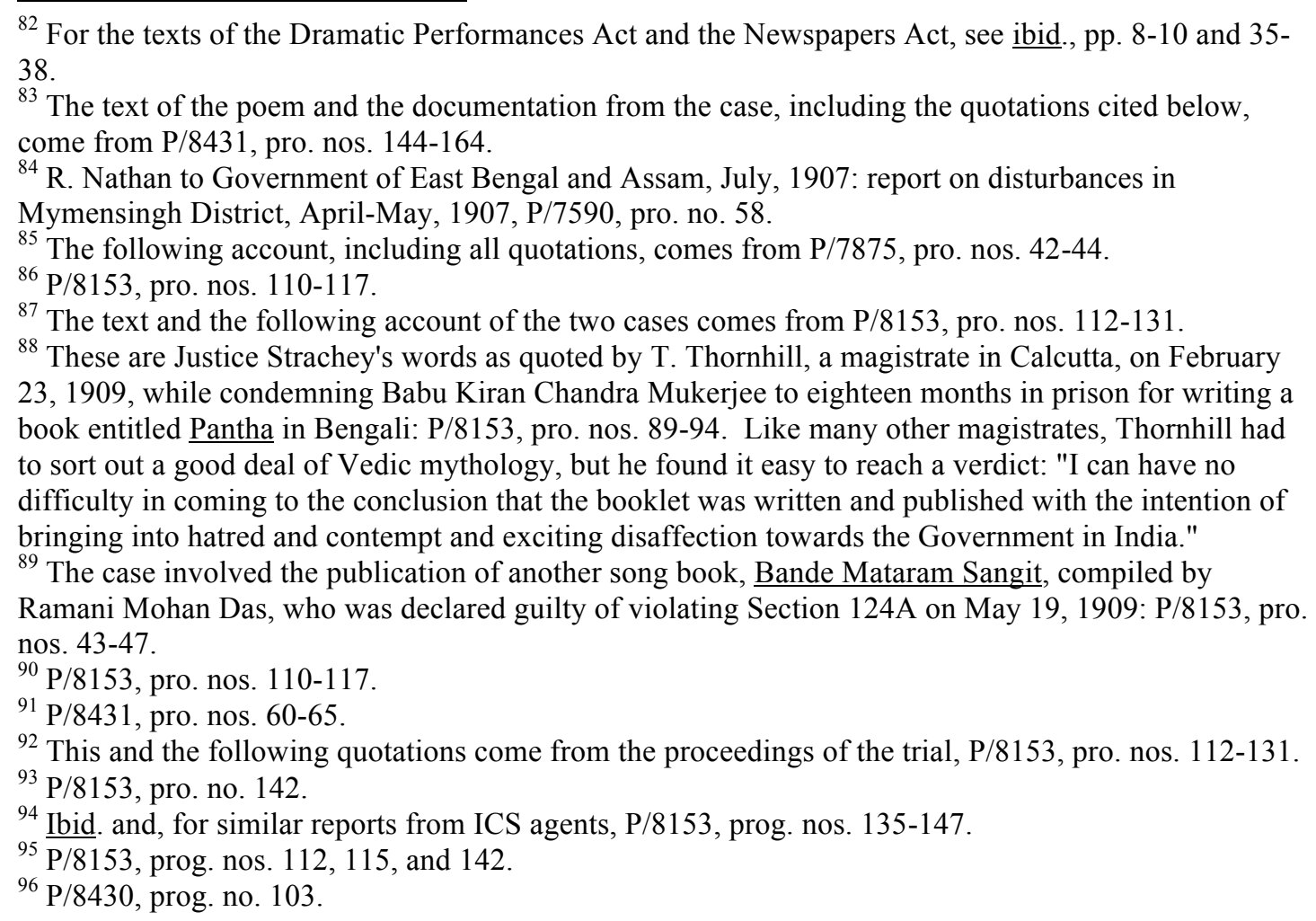

